\title{
High Performance Paper
}

\author{
by \\ Katsumi Kuboshima \\ Shizuoka Prefectural Research Institute of Pulp and Paper industry, \\ 3363, Dembo, Fuji-shi, Shizuoka 417
}

The title of this review, "High Performance Paper," was named after the High Performance Paper Society, which has been working on researches of specialities and/or characteristics of paper for twenty-five years. The " high performance paper" may be classified among the "special paper" in the paper industry, though the difference is not very clear at present.

This review describes recent developments in the manufacturing of the high performance paper in the modern sense. The following three groups of newly developed high performance paper and their properties are discussed:

1) Paper made with inorganic, carbon and metallic fiber and with other materials.

High performance of this group of paper is based on properties of raw materials.

2) Paper used for separation technology. Separation function of the paper originates in the structure of paper.

3) "Paper Ceramics." New characteristics appear through treatments of paper.

Key words: High Performance Paper/Special paper/Inorganic fiber / Carbon fiber / Metallic fiber / Separation technology / Paper ceramics

\section{機 能 紙 の 現 状と 期 待}

\author{
久 保 嶋 勝 巳* \\ （原稿受理：1987年 3 月17日）
}

\section{1. はじめに}

日本レオロジー学会第13年会のシンポジウム「レオロジーの応 用」で講演した「無機繊維紙」の内容を,「機能紙」と改めて, 現在，製紙業界に括いて展開しつつある技術的思想の一端を紹介 したい之思う。

最近，当該業界において「機能紙」が注目されているが，著者 も属する「機能紙研究会」1)の先駆的活動に依るところが大であ ると思われる。この会は, 21 年の歴央を有する「化繊紙研究会」 を継承し，現在の名称に改称して（昭和58年）今日に至っている ものであるが，改称に当たり，「機能紙」と当該業界で既に慣用 されてきた「特殊紙」との性格上の境界を設定するのに苦心した。 当会の英語名 ${ }^{2)}$ から知られるように, 「機能紙」を「仕事, 作用, 働きをする紙」であり「従来紙では垟成が困難な性能を有する紙」

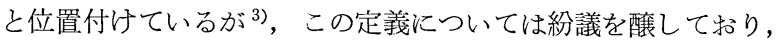

* 静岡県製紙工業試験場 $\quad \mathbf{T} 417$ 富士市伝法3363
未だ明確化されていない状況にある゙).

表 $1 \cdot 1$ 機能紙研究会誌㹸る研究対象の変遷

\begin{tabular}{|c|c|c|c|}
\hline $1962-1964$ & \multicolumn{3}{|c|}{ 化学的変成緘維（レーヨン，アセテートなど） } \\
\hline $1965-1967$ & 合 & 成 繊 & $\begin{array}{l}\text { 維（アクリル繊維，ポリプロピレ } \\
\text { ン瀻維） }\end{array}$ \\
\hline $1968-1970$ & 無 & 機 & $\begin{array}{l}\text { 維（ガラス繊維，金属緎維，アス } \\
\text { ベストなど） }\end{array}$ \\
\hline $1971-1973$ & 混 & & $\begin{array}{l}\text { 在（炭素繊維, 合成パルプ, 耐熱 } \\
\text { 繊維など） }\end{array}$ \\
\hline $1974-1976$ & 機 & 能 & $\begin{array}{l}\text { 化 (熱接着, 伸延, 耐熱, 耐久性 } \\
\text { など) }\end{array}$ \\
\hline $1977-1979$ & 機 & 能 & 化（吸水，混抄，複合など） \\
\hline $1980-1982$ & 機 & 能 & $\begin{array}{l}\text { 化 (イオン交換, 異種素材接合, } \\
\text { 導電, 静電除去など) }\end{array}$ \\
\hline 1984一現在 & & 生無機 & 材 (電磁シール, 不燃, 金属繊維, \\
\hline
\end{tabular}


表2・1 紙の性質を支配する重要因子と機能5)

\begin{tabular}{|c|c|c|c|c|c|c|}
\hline & & & & 長所の助長执よび短户 & †の改良のための方法 & \\
\hline & 程 の & 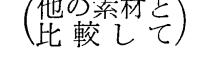 & & on machine & off machine & 用 \\
\hline & 乾 燥 強 度 & 適度に強い & (1) セルロース分子 & $\begin{array}{l}\text { パルプの選択, 叮解 } \\
\text { によるマブリル化, } \\
\text { 紙力增強剤の添加 }\end{array}$ & 補強用樹脂の含浸他 & $\begin{array}{l}\text { 包装紙全般, 積層板, } \\
\text { 化粧板 }\end{array}$ \\
\hline 学 & 湿 潤 強 度 & 弱い & $\begin{array}{l}\text { (2) 構造 } \\
\text { 度 }\end{array}$ & 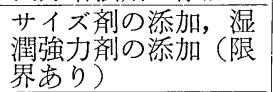 & 同 上 & $\begin{array}{l}\text { 紙タオル, テ自一水系塗工厚紙 } \\
\text { ッグ }\end{array}$ \\
\hline 的 & 剛 & $\begin{array}{l}\text { 㫏が強い } \\
\text { 性少ない }\end{array}$ & $\begin{array}{l}\text { (3) 綫維のずべりに } \\
\text { 破断への摩 } \\
\text { 擦抵抗 } \\
\text { (4) 䋐維間結合の強 }\end{array}$ & $\begin{array}{l}\text { パルプの選択 (リン } \\
\text { ター他), 墳料の添加 }\end{array}$ & 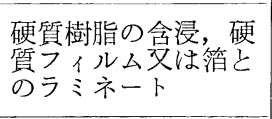 & 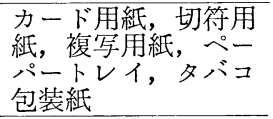 \\
\hline 性 & 塑 性 · 変形性 & 比較的あり & さと数 & パルプの選択他 & 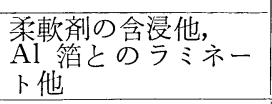 & $\begin{array}{l}\text { その他折りたたみ性 } \\
\text { が必要な用途 }\end{array}$ \\
\hline & 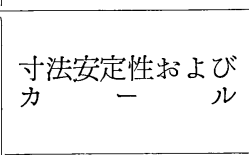 & 湿度変化に対し & & 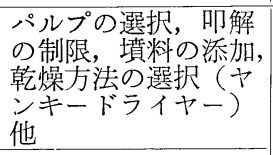 & 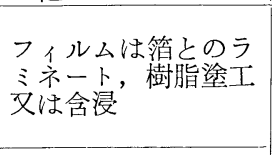 & $\begin{array}{l}\text { 地図用紙, 各種記録 } \\
\text { 縟, 粘着紙, 剝離紙 } \\
\text { 等加工紙全般 }\end{array}$ \\
\hline 华 & 防 湿 (水) 性 & 不良 & & サイズ剤の使用 & 同 上 & $\begin{array}{l}\text { 各種包装紙 (PVDC } \\
\text { 䋡工紙, ワックス紙 } \\
\text { 他) }\end{array}$ \\
\hline 形 & 吸 湿（水）性 & 良 & $\begin{array}{l}\text { （1） セルロースの反 } \\
\text { 忘性 } \mathrm{OH} \text { 基の存 }\end{array}$ & $\begin{array}{l}\text { パルプの選択, サイ } \\
\text { ズ剤の制限他 }\end{array}$ & 吸湿剤添加 & 紙タイル，紙オムツ \\
\hline 造 & 耐 油 (脂) 性 & 吸油性大 & $\begin{array}{l}\text { (2) 柋材綫維の形態 } \\
\text { 学的橿造 } \\
\text { (3) 䋐維集合体の構 }\end{array}$ & $\begin{array}{l}\text { 粘状吒解による緻密 } \\
\text { 华, 撜油性サイズ斉 } \\
\text { (フッ素樹脂)の添加 }\end{array}$ & $\begin{array}{l}\text { 硫酸処理, 耐油性樹 } \\
\text { 脂の塗工又はラミネ } \\
\text {-上 }\end{array}$ & $\begin{array}{l}\text { ペーチメント紙, グ } \\
\text { ラシン紙, 耐油紙 }\end{array}$ \\
\hline $\begin{array}{l}\text { 脑 } \\
\text { 関 } \\
\text { g } \\
\end{array}$ & 多 孔 性 & 通気性, 含浸性 & & $\begin{array}{l}\text { パルプの選択, 吒解 } \\
\text { の制限他 }\end{array}$ & & $\begin{array}{l}\text { 含浸用厚紙, フィル } \\
\text { 多ーペーパー }\end{array}$ \\
\hline 性 & ガスバリヤー性 & 低い & & $\begin{array}{l}\text { サイズプレス加工の } \\
\text { 強化等 (限度あり) }\end{array}$ & $\begin{array}{l}\text { バリヤー性ある材料 } \\
\text { との複合 }\end{array}$ & 保香紙, 食品包装紙 \\
\hline & 反応性 & $\begin{array}{l}\text { 染色性, 华学反 } \\
\text { 応性, 污染性 }\end{array}$ & & & & $\begin{array}{l}\text { 有機溶剤系塗工用厚 } \\
\text { 䋊 }\end{array}$ \\
\hline & 不 透 明 性 & 高い & & $\begin{array}{l}\text { パルプの選択, 吒解 } \\
\text { の制限, 墳料の添加 } \\
\text { 他 }\end{array}$ & $\begin{array}{l}\text { 顔料塗工, Al 箔の } \\
\text { 今 } \\
\text { 着他 }\end{array}$ & $\begin{array}{l}\text { 辞典用紙, チタン紙, } \\
\text { 临光性包装紙 }\end{array}$ \\
\hline $\begin{array}{l}\text { 光 } \\
\text { 学 }\end{array}$ & 透 明 性 & 低い & $\begin{array}{l}\text { (1) 木忉䋐維細胞中 } \\
\text { のルーメンの空 }\end{array}$ & 同上, 吅解, プレス, & $\begin{array}{l}\text { セルロースの屈折摔 } \\
\text { に近い材料の含浸 }\end{array}$ & $\begin{array}{l}\text { トレーシングペーパ } \\
\text { ー, 第 } 2 \text { 原図用紙, } \\
\text { グラジン緍 }\end{array}$ \\
\hline $\begin{array}{l}\text { 的 } \\
\text { 性 }\end{array}$ & 光 & 低い & $\begin{array}{l}\text { (2) 気 } \\
\text { 繊維集合体とし } \\
\text { ての縒層中の空 } \\
\text { 気 }\end{array}$ & $\begin{array}{l}\text { カンンダ強化, 墳料 } \\
\text { の添加, オンマン } \\
\text { コート }\end{array}$ & $\begin{array}{l}\text { 顔料塗工, A1 簿の } \\
\text { 烝着 }\end{array}$ & $\begin{array}{l}\text { 印刷ユート紙, 金属 } \\
\text { 光沢紙, 豊色紙 }\end{array}$ \\
\hline 質 & 色 & $\begin{array}{l}\text { 黄色味帯びた白 } \\
\text { 色 }\end{array}$ & & 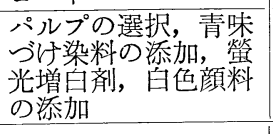 & 白色顔料の塗工 & 同 上 \\
\hline & 平＼cjkstart滑 & 低い & 水の存在下に抹 & プレス, カレンダの & $\begin{array}{l}\text { 顔料塗工, スースー処理他 } \\
\text { カ }\end{array}$ & 同上虽離紙，工程紙 \\
\hline $\begin{array}{l}\text { 裔 } \\
\text { 面 } \\
\text { 性 }\end{array}$ & 接 着 性 & 良い & $\begin{array}{l}\text { (2) 七ル形成 } \\
\text { 七維集合体 } \\
\text { 七緎維 }\end{array}$ & & $\begin{array}{l}\text { 接着増進プライマー } \\
\text { 㳑工, コロナ処理 } \\
\text { 他 }\end{array}$ & $\begin{array}{l}\text { 各種叙工紙, ラミネ } \\
\text { ト紙の基材 }\end{array}$ \\
\hline 厠 & 表 面 強 度 & 低い & & $\begin{array}{l}\text { サイズ風の強化， サ } \\
\text { イズプン加 }\end{array}$ & 樹脂塗工 & 印刷用紙 \\
\hline & 耐 熱 (寒) 性 & 良い & $\begin{array}{l}\text { セルロース分于 } \\
\text { の構造 }\end{array}$ & $\begin{array}{l}\text { 無機材料, 耐熱性高 } \\
\text { 分子材料の利用 }\end{array}$ & $\begin{array}{l}\text { シアノェチル化など } \\
\text { の化学処理他 }\end{array}$ & 耐熱絶縁紙 \\
\hline $\begin{array}{l}\text { 熱 } \\
\text { 的 } \\
\text { 性 }\end{array}$ & 燃焼 性 & あり & $\begin{array}{l}\text { 極性基として } \\
\mathrm{OH} \text { 基を有し, } \\
2 \text { 回うセン軸を }\end{array}$ & $\begin{array}{l}\text { 同上，および難燃剤 } \\
\text { の添加 }\end{array}$ & $\begin{array}{l}\text { 同上, 特よび難燃剤 } \\
\text { の叙工又は含浸 }\end{array}$ & $\begin{array}{l}\text { 難燃壁紙, 防炎紙, } \\
\text { 䋨打ち }\end{array}$ \\
\hline 質 & 熱 可 塑 性 & なし & $\begin{array}{l}\text { bった典型的立 } \\
\text { 烋規則性結晶性 } \\
\text { 高分子 }\end{array}$ & $\begin{array}{l}\text { 鿖成パルプの混抄, } \\
\text { 熱性樹脂のプ } \\
\text { セル化 }\end{array}$ & $\begin{array}{l}\text { 熱可塑性樹脂の塗工 } \\
\text { 䒘ート }\end{array}$ & $\begin{array}{l}\text { ヒートシール用紙 } \\
\text { (防湿紙, ミルクカ } \\
\text {-トン) }\end{array}$ \\
\hline 電 & 電 気 絶 縁 性 & 比較的あり & & $\begin{array}{l}\text { パルプの選択, 脱イ } \\
\text { オン水の使用他 }\end{array}$ & 絶縁性樹脂の含浸 & $\begin{array}{l}\text { 電気絶縁紙（コンデ } \\
\text { 芫苗ーパー）, } \\
\text { 積層板 }\end{array}$ \\
\hline 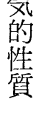 & 導＼cjkstart電 & なし & " & $\begin{array}{l}\text { 導電性樹脂, カーボ } \\
\text { 加ブラッグ添 } \\
\text { 加 }\end{array}$ & 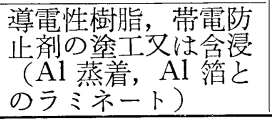 & $\begin{array}{l}\text { 電気感応記録紙 (静 } \\
\text { 電, 放電, 電子写 } \\
\text { 真), 带電防止紙 }\end{array}$ \\
\hline
\end{tabular}


近代製紙は約 100 年を経ようとしており，この間に製紙産業は 豊富な経験を資産として, 極めて生産性の高いシート化技術を蓄 積してきた，植物性䋞維を水に分散し，漉さ上げて「紙」にする という作業は, 約2000年前の古代紙の製法と基本的には同一の原 理に基づくものである. 対象となる「紙」の原料は, 親水性に富 む天然セルロース系が主であり, 現在でも「親水性繊維」の占め る地位は変らない. 現在, 国内で約 950 万トンの木材パルプが生 産されていると推定され，「紙」と言兄ば「親水性䋐維からなる シート物」であり, 製紙産業は「親水性緘維」を取り扱う産業と いう概念が定着してきた。

しかし, ここ30年間に発達した素材開発に触発されて, 従来の 製紙技術の範囲を越えて新たな領域が開かれてきた。例えば， 「機能紙研究会」の25年間の研究経過（表 1 1 1) によって知ら れるように，非セルロース系㵶維を対象としたシート化技術の展 開である.これらの技術は長い「紙」の歴史から見れば極めて最 近のものであり，またようやくシート化の目途が開かれたにすぎ なくて，未だ現実の生産技術が確立されたわけではない、シート 化技術自体も，今な敃従来技術の延長線上で検討されている段階 であり，その物性・機能の評価方法沶よび用途開拓の面でも多く の課題が残されている.

しかし，生産現場の経験から，特許技術など多くの技術が無関 係に開示されつつある状況にあり, 今後, どのような状沉になる か予想ができない分野でもある，今後，これらの「新規材料」の 体系的研究が行われる必要を痛感せざるを得ない。

ここでは著者らが実際に関与した「機能紙」を实例にして, 「紙の機能化」という問題を考えてみたい。

\section{2. 紙の機能化に関する思想}

近年, 「機能……といら言葉 (用語) が氾濫している. 先に も触れたように，「機能紙」なる呼称を設定するに当たり様々な 考えが提起され，「性能」と「機能」の雨概念をどのように定義 するか判然としないまま暫定的に，先に触れた位置付子をした。

当該業界において「機能紙」なる名称が使われだしたのは，こ こ 5 年ぐらいのことだと思う。以前は「特殊紙」なる名称が慣用 され，今日，乱用されている「機能紙」も「特殊紙」の一概念と してされて抢り，不都合があったわけではないい．

従来，「紙の機能化」または「高性能化」と言えば，表 2 . $1^{5)}$ 亿例示したようなセルロース紙の持つ特性の改善, または改 良を意味した。しかし，今日言われている「機能化」とは，本来 の「紙」では対象にはなり得ない分野にまで作用させようとする 素材設計の意志を包含している，例塈ば，本来「紙」は「燃える もの」としてきたが，無機䋐維などのシート化により「不然物」 として, 高熱部の保護材への展開などである. 更に, 「紙」飞他 の作用機構を与えることで, 作用効果を「紙」汇求めるのでなく, 付与された作用機棈に求め, 「紙」は単なる媒介物としか考兵な い指向もある. 例之ば, 紙の多孔性を利用して, 酵素, 微生物の 担体として，そのシート物の作用効果は「シート」にあるのでな く, 適用した物質の作用效果酒值を求めている ${ }^{6)}$.

このような状況が生じた背景には, 製紙産業が蓄積した高度な シート化技術と素材開発の進展があり，「紙の機能化」に関する 思想がますます広義にとらえられつつある。

表 $2 \cdot 2^{7}$ 扣よび表 $2 \cdot 3^{8)}$ は, 機能紙の概念を材料または作
表 $2 \cdot 2$ 高機能性繊維と紙の機能化 ${ }^{7)}$

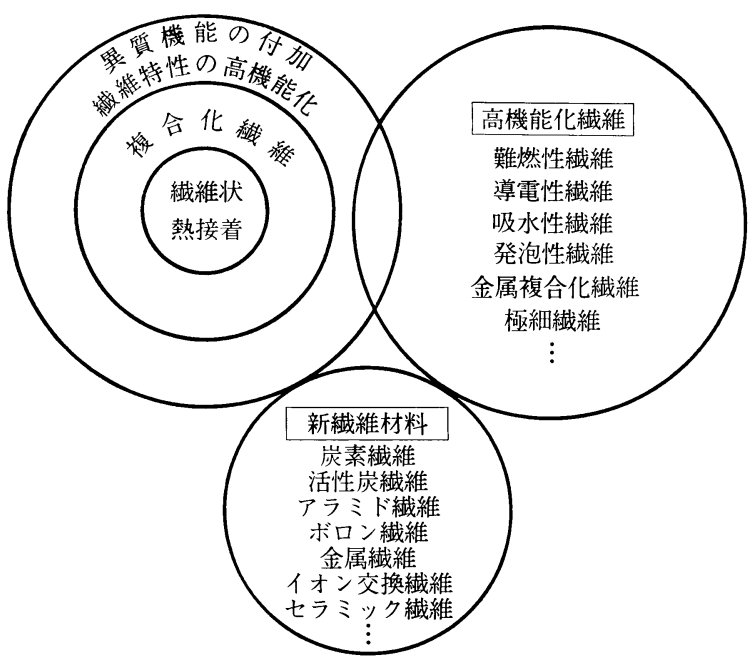

用から考察した例である。

著者の私見ではあるが，「紙の機能化」とは明確な用途を設定 し，その用途に適合する作用機構を創作する行為と考兄ている。 このように考劣ると, ことさら機能紙と言わなくとも, 我々の周 辺には必要とされる機能要件を満たさなければならない「紙」は まだまだ多い，表 $2 \cdot 4$ 亿想定されるるのを例示した，また，表 2 ・5 亿例示したような異種技術の境界に, 従来紙とは異なる新 規用途が想定される．今日のいわゆる「先端材料」の出現と共に， 従来紙では対象外であった分野への進出が可能となりつつある.

\section{3. 機能紙の実際}

「機能紙」なる所以を何処に求めるかは諸説があり, 定説化し たるのは無いと思われる. 著者の独断ではあるが,「機能」の实 体を「需要・用途」と関係付けて考它たい，例えば，著者らはエ ビ，カニなど甲殼類の甲殼を構成する成分である「キチン」の誘 導体である「キトサン」を適用したスピーカー・コーン紙を発表 したが ${ }^{9)}$ ，オーディオの世界では音の発生源であるスピーカー・ コーン紙の振動特性と関連して,「良い音色」つまり「感性」が 設計目標であり，「良い音作り」が「機能化」の寒体である。 た食品容器などでは, 被包装物の異常な着香・着色を極度に嫌い， 「資材の無臭・实定化」も用途目的から見れば「機能」の実体と 言えよう。

ここでは著者の私見ではあるが，「紙状シート」の褠成要素から 「機能発現」を考察し, 読者の批判を受けたいと思っている。

\section{$3 \cdot 1$ 材料の特性を利用した機能}

表 $3 \cdot 1 \cdot 1$ 亿示したよ5な「無機繊維」茥) は, 耐熱, 耐薬品性, 電気特性に優れているから, これらの特性を活かし, 電池隔壁材, 熱交換/蓄熱資材, 触媒担体, 防懪性防塵フィルタ, 耐熱性摩擦 板なぞ期待される用途も多い(表 $3 \cdot 1 \cdot 2)$.

また岑素㵶維 (表 $3 \cdot 1 \cdot 3)^{11), 12)}$, 金属繊維 $(\text { 表 } 3 \cdot 1 \cdot 4)^{13)}$ の場合は, 通電機能を有することから, 静電気除去, 電磁波遮蔽 を目的とした精密電子部品保護資材の分野が期待されている.

更に, 活性炭素纎維（表 $3 \cdot 1 \cdot 5)^{14)}$ では吸着機能を活かして, 生鮮野菜/果実の鮮度保持資材なぞが開発されつつある. 更に, イオン交換瀻維 (表 $3 \cdot 1 \cdot 6)^{15}$ ) シートの分離紙が, また酵素固 
表 $2 \cdot 3$ 機能性セルロ一

\begin{tabular}{|c|c|c|c|}
\hline 能 & 例 & 能 & 例 \\
\hline $\begin{array}{l}\text { 成形材料と } \\
\text { し }\end{array}$ & 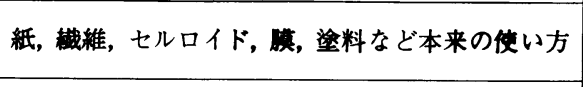 & 誘 電 性 & $\begin{array}{l}\text { Cell-OCH }{ }_{2} \mathrm{CH}_{2} \mathrm{CN} \\
\text { Cell-O }\left(\mathrm{CH}_{2}\right)_{2} \mathrm{O}\left(\mathrm{CH}_{2}\right)_{2} \mathrm{CN}\end{array}$ \\
\hline 反 応 性 & 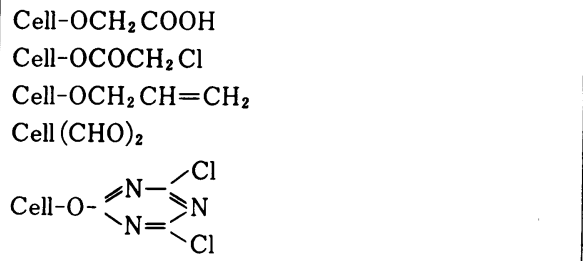 & 発色, 発光 & 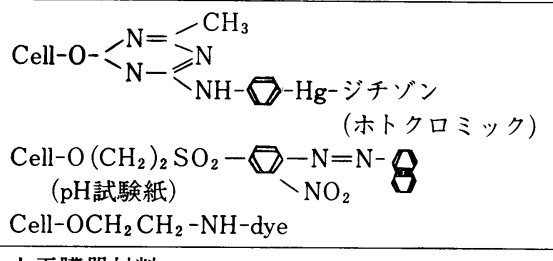 \\
\hline \multirow{2}{*}{$\begin{array}{l}\text { グラフト幹 } \\
\text { 橋架け用 } \\
\text { 分解性 }\end{array}$} & \multirow{2}{*}{$\begin{array}{l}\mathrm{Cell}-\mathrm{OAc} \\
\mathrm{OCO}\left(\mathrm{CH}_{2}\right)_{2} \mathrm{CH}-\mathrm{CH}_{2} \\
\text { Cell-O-CS-SNa} \\
\text { Cell- }-\mathrm{OCOCH}{ }_{2} \mathrm{~S}-\mathrm{SO}_{3} \mathrm{Na}\end{array}$} & 用 & $\begin{array}{l}\text { 人工臟器材料 } \\
\text { アセテート } \\
\text { Cell-OSiMe }_{3}\end{array}$ \\
\hline & & \multirow[t]{2}{*}{ 安定剤固定 } & $\begin{array}{c}\text { Cell- } \mathrm{OCH}_{2} \text { ○一 } \mathrm{Fe}-\text { (防腐性) } \\
\text { フェロセニイルメルセルロース }\end{array}$ \\
\hline \multirow{3}{*}{$\begin{array}{l}\text { キレート } \\
\text { 形 } \\
\text { 成 }\end{array}$} & \multirow{3}{*}{$\begin{array}{l}\text { Cell-OSO }{ }_{3} \mathrm{H} \\
\mathrm{Cell}-\mathrm{OP}(=\mathrm{O})(\mathrm{OH})_{2} \\
\mathrm{CH}_{2} \mathrm{O} \text { どで橋架け後一 } \mathrm{CH}_{2} \mathrm{COOH} \text { 化, DEAE化 } \\
\mathrm{Cell}=\mathrm{O}\left(\mathrm{CH}_{2}\right)_{\mathrm{n}} \mathrm{SO}_{3} \mathrm{Na} \quad \text { (両性電解質) } \\
\quad \mathrm{OCH}_{2} \mathrm{CH}_{2} \mathrm{NEt}_{3} \quad\end{array}$} & & Cell-R-(o-ヒドロキシベンゾフェノシ) \\
\hline & & 界面 活 性 & $\begin{array}{ll}\text { anionic } & \mathrm{Cell}_{\text {neCH }} \mathrm{COONa} \\
\text { nonionic } & \text { Cell-OEt } \\
& \text { (凝集分散郕) } \\
\end{array}$ \\
\hline & & & $\begin{array}{l}\mathrm{Pd} \text { の担体（不斉還元用） } \\
\text { ビニルモくーの無触腜重合 }\end{array}$ \\
\hline \multirow[t]{2}{*}{ 酸化 還 元 } & \multirow{2}{*}{ 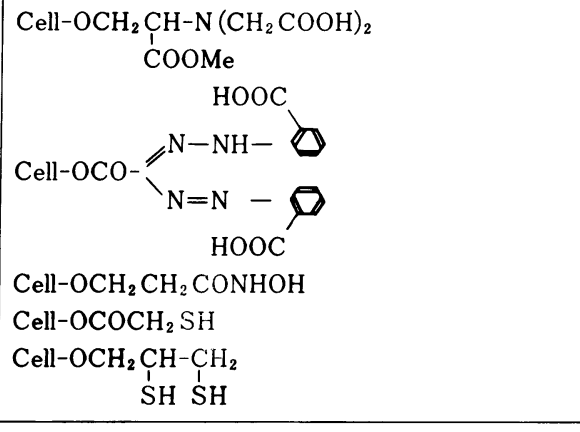 } & 高分子触媒 & 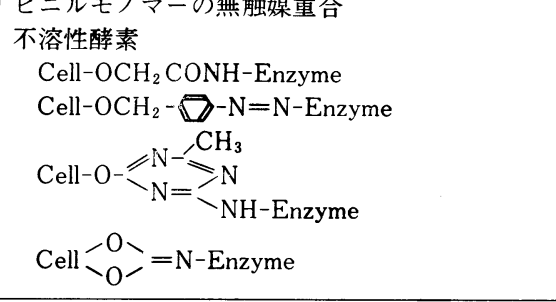 \\
\hline & & \multirow[b]{2}{*}{$\begin{array}{l}\text { マトリックス } \\
\text { として }\end{array}$} & $\begin{array}{l}\text { アフィニティークロマト固定相 } \\
\text { Cell-peptide } \\
\text { Cell-nucleotide }\end{array}$ \\
\hline 感 光 & $\begin{array}{l}\text { Cell-OCOCH }=\mathrm{CH}-\square \\
\quad \text { (光によるシワ回復性) } \\
\text { Cell-OCOCH}{ }_{2} \mathrm{~S}-\mathrm{CSNR}{ }_{2} \\
\text { Cell-OCOCH}{ }_{2} \mathrm{~S}-\mathrm{CSOR}\end{array}$ & & $\begin{array}{l}\text { DEAE } \\
\text { ECTEOLA } \\
\text { CT-ドナー(クロマト固定相), アクセプター } \\
\text { 各種吸着剤 } \\
\text { オリココ核酸合成支台など }\end{array}$ \\
\hline
\end{tabular}

表 $2 \cdot 5$ 技術境界と紙の接点（例）

表 $2 \cdot 4$ 過去に話題となった紙と機能（例）

\begin{tabular}{|c|c|c|}
\hline 能 & 昭和(年) & 用 \\
\hline $\begin{array}{l}\text { リン酸セルロース・イ } \\
\text { オン交換繊維紙 }\end{array}$ & $\sim 35$ & $\begin{array}{l}\text { アルコール, 酒, 液体食品の } \\
\text { 脱鉄 }\end{array}$ \\
\hline 無臭紙 ～～～～～～～～～ & $\sim 35$ & $\begin{array}{l}\text { 酒自動販売機用の紙コップ, } \\
\text { 加昷食品の紙容器, 有香食品 } \\
\text { の包装紙 }\end{array}$ \\
\hline 無臭・耐水紙 & $\sim 40$ & $\begin{array}{l}\text { コーヒー, 緑茶などの抽出バ } \\
\text { ッグ }\end{array}$ \\
\hline 通気・防湿紙 & $\sim 40$ & 納豆䤇酵容器など \\
\hline 非滑性紙 & $\sim 45$ & 重袋の滑落防止 \\
\hline 臨床用検査紙 & $\sim 50$ & $\begin{array}{l}\text { 糖尿, 肝臟/腎臓疾患などの } \\
\text { 査 }\end{array}$ \\
\hline 防カビ, 防菌, 殺菌紙 & $\sim 55$ & 各種包装用紙 \\
\hline 高吸水紙 & $\sim 55$ & 生理用品, 衛生紙, 紙オムツ \\
\hline 脱臭紙 & $\sim 55$ & 靴中敷紙，衛生·看護用紙 \\
\hline
\end{tabular}

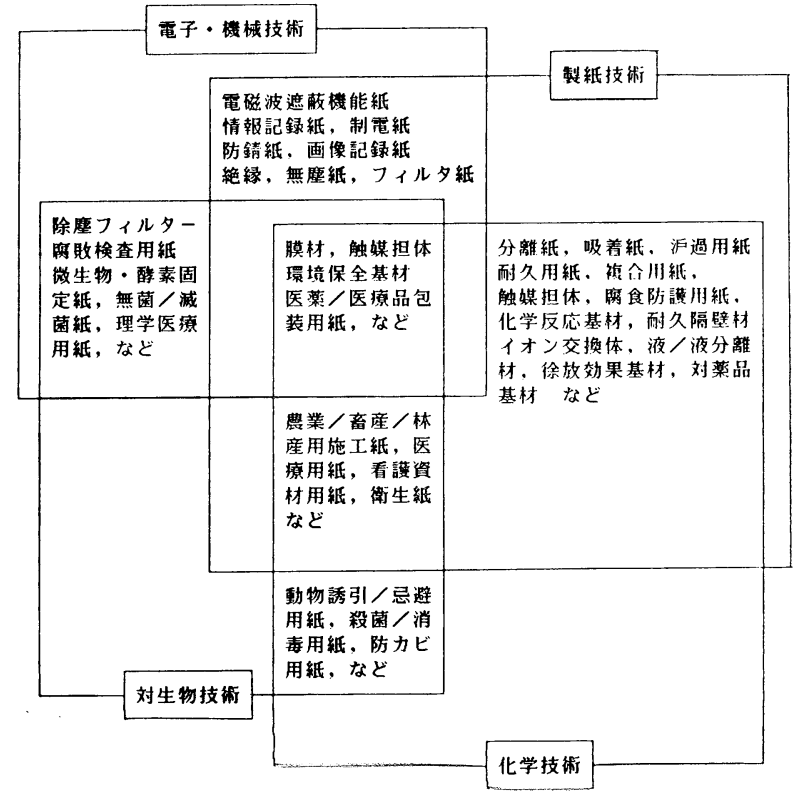


表3・1・1 紙に使用される無機繊維と性質 ${ }^{10)}$

\begin{tabular}{|c|c|c|c|c|c|c|c|c|c|}
\hline 維 & 成 & $\begin{array}{l}\text { 密 度 } \\
\mathrm{g} / \mathrm{cm}^{3}\end{array}$ & $\begin{array}{l}\text { 繊維径 } \\
\mu \mathrm{m}\end{array}$ & $\mid \begin{array}{l}\text { 引張強度 } \\
\mathrm{kg} / \mathrm{mm}^{2}\end{array}$ & $\begin{array}{c}\text { 引張弾性 } \\
\mathrm{t} / \mathrm{mm}^{2}\end{array}$ & $\begin{array}{l}\text { 融解温度 } \\
\stackrel{C}{C}\end{array}$ & $\mid$ & 特奉欠点 & $\begin{array}{l}\text { 紙の } \\
\text { 開発 }\end{array}$ \\
\hline 石 & $\begin{array}{r}3 \mathrm{MgO} \cdot 2 \mathrm{SiO}_{2} \cdot \\
2 \mathrm{H}_{2} \mathrm{O}\end{array}$ & $2.4 \sim 2.6$ & $\begin{array}{r}1.4 \\
(2 \sim 30)\end{array}$ & $56 \sim 75$ & & 1,500 & 550 & 柔軟性, 耐熱性大 & \\
\hline 石 綿 青 石 綿 & $\begin{array}{l}\mathrm{NaFe}\left(\mathrm{SiO}_{3}\right) \\
\mathrm{FeSiO}_{3} \cdot \mathrm{xH}_{2} \mathrm{O}\end{array}$ & $3.2 \sim 3.3$ & $\left(\begin{array}{c}9 \\
(2 \sim 30)\end{array}\right)$ & $75 \sim 225$ & & 1,200 & & 柔軟性, 耐酸性大 & 第 \\
\hline アモサイト & $\begin{array}{l}\left(\mathrm{Fe}_{2} \mathrm{Mg}\right) \mathrm{SiO}_{3} \\
\quad \sim \sim 5 \% \mathrm{H}_{2} \mathrm{O}\end{array}$ & $\mid 3.1 \sim$ & $\left(\begin{array}{c}10 \\
(5 \sim 50)\end{array}\right.$ & $11 \sim 63$ & & 1,400 & 300 & $\begin{array}{l}\text { 緎維太くもろい, } \\
\text { 温材 }\end{array}$ & $\begin{array}{l}\text { 世 } \\
\text { 代 }\end{array}$ \\
\hline 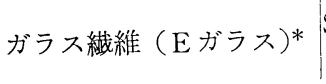 & $\mid \begin{array}{r}\mathrm{SiO}_{2} \cdot \mathrm{CaO} \cdot \mathrm{Al}_{2} \mathrm{O}_{3} \\
\mathrm{Be}_{2} \mathrm{O}_{3} \mathrm{MgO}\end{array}$ & 2.54 & $3 \sim 15$ & $140 \sim 150$ & 7.4 & $840^{\circ} \mathrm{C}$ 軟化 & 400 & $\begin{array}{l}\text { 笓較的安価, 沉用 } \\
\text { 材 }\end{array}$ & \\
\hline 炭 素 繊 維 & $\mathrm{C}$ & $1.5 \sim 2.0$ & $6 \sim 8$ & 280 & 23 & $\begin{array}{l}\text { 霣围気で大 } \\
\text { 異なる }\end{array}$ & & 軽量 & \\
\hline 黒 鉛 䋐 維 & $\mathrm{C}$ & 1.9 & $6 \sim 8$ & 220 & 40 & & & 高弾性率 & \\
\hline 高 硅 酸 䋐 維 & $\mathrm{SiO}_{2}$ & 2.3 & $0.1 \sim 13$ & 80 & 7 & 1,660 & 1,100 & 耐触性大 & 第 \\
\hline アルミナ・シリカ繊維 & $\begin{array}{c}\mathrm{Al}_{2} \mathrm{O}_{3} / \mathrm{SiO}_{2} \\
4 \sim 6: 6 \sim 4\end{array}$ & $2.6 \sim 3.2$ & $1 \sim 5$ & 130 & 12 & $1,700 \sim 1.090$ & $870 \sim 1,400$ & 生産性高い & 二 \\
\hline アルミナ 繊 維 & $\mathrm{Al}_{2} \mathrm{O}_{3}$ & $3.2 \sim 3.5$ & 9 & 260 & 25 & 2,000 & $1,500 \sim 1,700$ & 耐熱性大 & \\
\hline ムライト 繊 維 & $\begin{array}{c}\mathrm{Al}_{2} \mathrm{O}_{3} / \mathrm{SiO}_{2} \\
8: 2\end{array}$ & $2.9 \sim 3.0$ & $2 \sim 8$ & & & $1,850 \sim 2,000$ & 1,600 & 耐熱性大 & 世 \\
\hline 炭 化ケイ素繊 維 & $\mathrm{SiC}$ & 2.5 & 13 & 250 & 20 & & 1,200 & & 代 \\
\hline ホウ 素 㵶 維 & Bの結晶 & 2.6 & 100 & $320 \sim 400$ & 42 & 2,450 & & $\begin{array}{l}\text { 高弾性率, 高強度 } \\
\text { 耐熱性大 }\end{array}$ & 代 \\
\hline チタン酸カリウム繊維 & $\mathrm{K}_{2} \mathrm{Ti}_{6} \mathrm{O}_{18}$ & 3.6 & 1 & 16.8 & & 1,371 & 1,200 & $\begin{array}{l}\text { 高温時の熱伝導淬 } \\
\text { 小 }\end{array}$ & \\
\hline サファイヤ綫維(単結晶) & $\alpha-\mathrm{Al}_{2} \mathrm{O}_{3}$ & 3.99 & \begin{tabular}{|c|}
250 \\
$(50 \widetilde{\sim}$ \\
$500)$
\end{tabular} & 240 & 46 & $2,000<$ & $\begin{array}{l}1,500 \sim \\
1,700<\end{array}$ & 高弾性率 & 第 \\
\hline \multicolumn{9}{|c|}{ ウイスカー**, アルミナ，酸化ベリリウム，窒素ケイ素，炭化ホウ素，黒鉛など } & \\
\hline
\end{tabular}

* 日東紡ガラス䋐維

** ウイスカーの性質は次表参照

\begin{tabular}{|c|c|c|c|c|c|c|c|c|c|}
\hline & & $\begin{array}{c}\text { 融点また } \\
\text { は軟华点 } \\
{ }^{\circ} \mathrm{C}\end{array}$ & $\begin{array}{l}\text { 密 度 } \\
\mathrm{g} / \mathrm{cm}^{3}\end{array}$ & $\begin{array}{l}\text { 引っぱり } \\
\text { 強 } \\
\mathrm{kg} / \mathrm{mm}^{2}\end{array}$ & $\begin{array}{l}\text { 比強さ } \\
\mathrm{cm} \times 10^{6}\end{array}$ & $\begin{array}{l}\text { たて弾性 } \\
\text { 係 数 } \\
\mathrm{kg} / \mathrm{mm}^{2}\end{array}$ & $\begin{array}{l}\text { 皆弾 性 } \\
\text { 数 } \\
\mathrm{cm} \times 10^{6}\end{array}$ & 直 $\mu^{\text {径 }}$ & 実用性 \\
\hline \multirow{6}{*}{ セラミック } & アルミナ $\left(\mathrm{Al}_{2} \mathrm{O}_{3}\right)$ & 2,040 & 3.96 & 2,110 & 53 & 43,600 & 1,100 & $3 \sim 10$ & 商 \\
\hline & 酸化ベリリウム $(\mathrm{BeO})$ & 2,570 & 2.85 & 1,340 & 47 & 35,200 & 1,230 & $10 \sim 30$ & 試 作品 \\
\hline & 炭化ホウ素 $\quad\left(\mathrm{B}_{4} \mathrm{C}\right)$ & 2,450 & 2.52 & 1,410 & 56 & 49,200 & 1,950 & - & 試 作 品 \\
\hline & 炭化ケイ素 $(\mathrm{SiC})$ & 2,690 & 3.21 & 2,110 & 66 & 49,200 & 1,540 & $<1 \sim 3$ & \\
\hline & 窒化ケイ素 $\left(\mathrm{Si}_{3} \mathrm{~N}_{4}\right)$ & 1,900 & 3.18 & 1,410 & 44 & 38,700 & 1,210 & - & 商品 \\
\hline & 黒＼cjkstart鉛 & 3,650 & 1.66 & 2,000 & 120 & 71,700 & 4,320 & - & 試作品 \\
\hline
\end{tabular}

表 $3 \cdot 1 \cdot 2$ 無機緎維紙の用途例

\begin{tabular}{|c|c|c|c|}
\hline 態 & 主 材 料 （例） & 製 造 設 備 & 用 \\
\hline 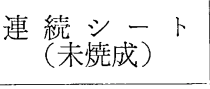 & \multirow{4}{*}{ 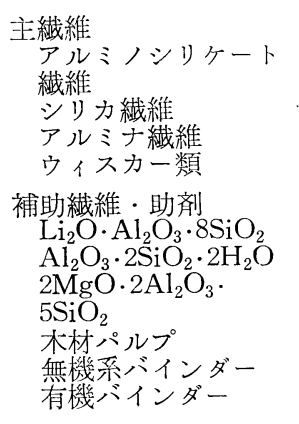 } & 抄紙機 & $\begin{array}{l}\text { 耐熱バッカー紙, 譬装用基材, 断熱ハニカムコア原紙, 複合基材, } \\
\text { 各種フィルー, 電池電極材 }\end{array}$ \\
\hline 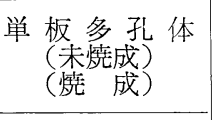 & & $\begin{array}{l}\text { 抄造プレス } \\
\text { メーキングロール }\end{array}$ & $\begin{array}{l}\text { 気体沪過材, 液体沪過材, 消音部材, 緩衝材, 散気板, 灯しん, 軽 } \\
\text { 量断熱材, 壁装横造材 }\end{array}$ \\
\hline $\begin{array}{c}\text { 高密度成形板 } \\
\text { (类焼成) } \\
\text { (焼 成) } \\
\end{array}$ & & $\begin{array}{l}\text { 抄造プレス } \\
\text { モールド成形 }\end{array}$ & 簡易基盤, 大形タイル，極薄音響振動板 \\
\hline $\begin{array}{l}\text { 立 傋成 形 体 } \\
\text { (焼成) } \\
\text { (焼 成) }\end{array}$ & & モールド成形 & 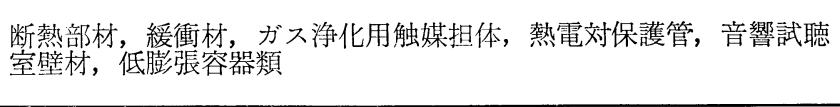 \\
\hline
\end{tabular}


表3 $1 \cdot 3$ 炭素䋐維紙と特性

$\mathrm{PVA} /$ 炭素繊維 $^{11)}$

\begin{tabular}{l|c|c|c|c|c}
\hline 炭 素 繊 維 & 50 & 60 & 70 & 80 & 90 \\
\hline 繊 維 状 PVA & 50 & 40 & 30 & 20 & 10 \\
\hline 米 坪 $\left(\mathrm{g} / \mathrm{m}^{2}\right)$ & 57.2 & 56.3 & 59.7 & 56.7 & 64.8 \\
厚 さ $(\mathrm{mm})$ & 0.31 & 0.31 & 0.39 & 0.375 & 0.43 \\
密 度 $\left(\mathrm{g} / \mathrm{cm}^{3}\right)$ & 0.19 & 0.18 & 0.15 & 0.15 & 0.15 \\
裂断長 $(\mathrm{km})$ & 6.2 & 5.2 & 4.0 & 3.6 & 1.54 \\
比 破 裂 強さ & 3.5 & 2.9 & 2.9 & 2.3 & 1.5 \\
伸 び (\%) & 2.0 & 1.3 & 0.8 & - & - \\
比抵抗 $(\Omega \mathrm{cm})$ & 0.48 & 0.45 & 0.44 & 0.43 & 0.36 \\
\hline
\end{tabular}

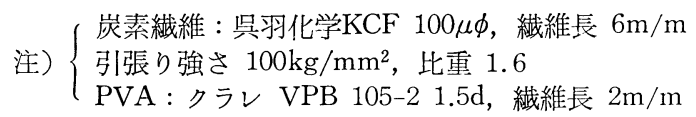

$\mathrm{Pulp} /$ 炭素繊維 $^{12}$

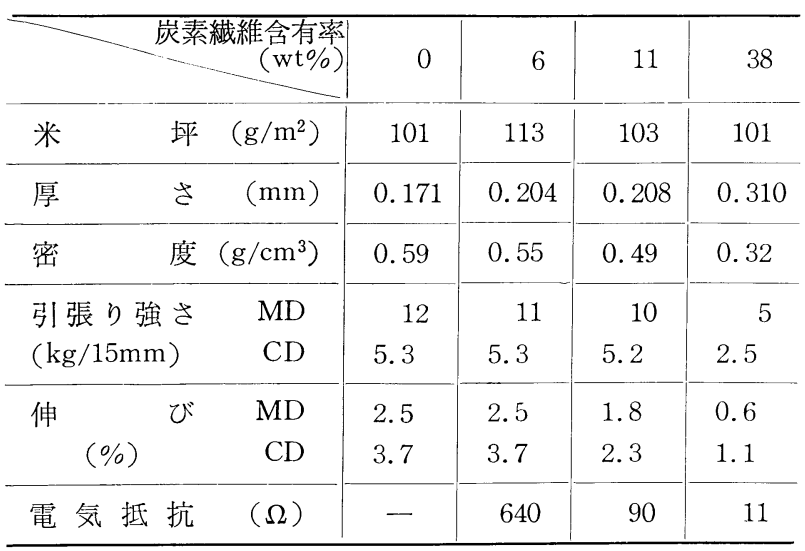

注) NBKP と炭素繊維クレハ KGF 200

表3・1・4 紲に使用可能な金属瀻維の性質 ${ }^{13}$

\begin{tabular}{|c|c|c|c|c|c|}
\hline & 鋼 & $\begin{array}{l}6-4 \\
\text { 黄 銅 }\end{array}$ & $\begin{array}{l}\text { アルミ } \\
\text { ニウム }\end{array}$ & $\begin{array}{l}\text { ガラス } \\
\text { 緎 維 }\end{array}$ & $\begin{array}{l}\text { ポリエ } \\
\text { チレン }\end{array}$ \\
\hline 密 $\left(\mathrm{g} / \mathrm{m}^{3}\right)^{\text {度 }}$ & 7.8 & 8.4 & 2.7 & 2.55 & 0.94 \\
\hline $\begin{array}{c}\text { 引張 り強さ } \\
\left(\mathrm{kg} / \mathrm{mm}^{2}\right)\end{array}$ & 40 & 34 & 23 & 200 & 3 \\
\hline 比 $\left(\mathrm{cal} / \mathrm{g}^{\circ} \mathrm{C}\right)^{\text {熱 }}$ & 0.12 & 0.09 & 0.23 & 0.19 & 0.55 \\
\hline 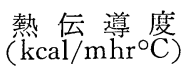 & 50 & 101 & 127 & 0.9 & 0.2 \\
\hline $\begin{array}{c}\text { 線 膨 張 率 } \\
\left(10^{-6} /{ }^{\circ} \mathrm{C}\right)\end{array}$ & 1.2 & 20 & 23 & 5 & 180 \\
\hline $\begin{array}{c}\text { 固 有抵 抗 } \\
(\Omega \mathrm{cm})\end{array}$ & $1.4 \times 10^{-5}$ & $6.2 \times 10^{-6}$ & $2.9 \times 10^{-6}$ & $10^{12}$ & $>10^{18}$ \\
\hline 耐 ${ }^{\text {融㪇点 }{ }^{\circ} \mathrm{C} \text { ) 性 }}$ & 1,540 & 960 & 560 & 750 & 120 \\
\hline
\end{tabular}

表3 $\cdot 1 \cdot 5$ 活性炭素綫維紙の性能14)

\begin{tabular}{|c|c|c|c|c|c|c|}
\hline \multicolumn{2}{|c|}{ 項 目 グレード } & 07 & 10 & 15 & 20 & 25 \\
\hline 比表面積 & $\mathrm{m}^{2} / \mathrm{g}$ & 700 & 1,000 & 1,500 & 2,000 & 2,500 \\
\hline 細 孔半径 & $\AA$ & 7 & 9 & 12 & 16 & 22 \\
\hline 細孔容積 & $\mathrm{ml} / \mathrm{g}$ & 0.12 & 0.22 & 0.50 & 0.75 & 1.20 \\
\hline ベン茂着 & $\mathrm{Wt} \%$ & 14 & 22 & 45 & 65 & 90 \\
\hline ヨード吸着量 & $\mathrm{mg} / \mathrm{g}$ & 750 & 950 & 1,550 & 2,000 & 2,400 \\
\hline $\begin{array}{l}\text { メチレン } \\
\text { ブルー脱色力 }\end{array}$ & $\mathrm{ml} / \mathrm{g}$ & 0 & 0 & 270 & 340 & 380 \\
\hline $\mathrm{pH}$ & & 7 & 7 & 7 & 7 & 7 \\
\hline & $\%$ & 0.03 & 0.03 & 0.03 & 0.04 & 0.05 \\
\hline 着 火温度 & ${ }^{\circ} \mathrm{C}$ & 470 & 470 & 470 & 470 & 470 \\
\hline
\end{tabular}

注）ビニロン炭化繊維

表3 $1 \cdot 6$ イオン交換繊維紙の性質 ${ }^{15}$

\begin{tabular}{|c|c|c|c|}
\hline 項 目 種 別 & Expapier ${ }^{\circledR}-1$ & Expapier ${ }^{\circledR F}-2$ & Expapier ${ }^{\circledR F}-3$ \\
\hline 外 & 茶 & 色 & 色 \\
\hline 官 能 基 & $\begin{array}{l}\text { スルホン酸 } \\
\text { ソーー多 }\end{array}$ & イミノジ酶酸 & $\begin{array}{l}\text { ア 級 } \\
\text { アンモニウム }\end{array}$ \\
\hline $\begin{array}{c}\text { 総 交 換 容 量 } \\
(\mathrm{mg} / \text { 枚 })\end{array}$ & 6.0 as $\mathrm{Na}^{+}$ & 5.5 as $\mathrm{Cu}^{2+}$ & 8.2 as $\mathrm{Cl}^{-}$ \\
\hline${ }^{\text {重 }}(\mathrm{g} / \text { 枚 })^{\text {量 }}$ & 0.34 & 0.29 & 0.28 \\
\hline 厚 $(\mathrm{mm})^{\text {म }}$ & 0.30 & 0.25 & 0.29 \\
\hline 坪 $\left(\mathrm{g} / \mathrm{m}^{2}\right)^{\text {量 }}$ & 200 & 170 & 160 \\
\hline $\begin{array}{l}\text { 沪過 速 度 } \\
\left(\mathrm{ml} / \mathrm{min} \mathrm{cm}^{2}\right)\end{array}$ & $\sim 1.0$ & $\sim 2.0$ & $\sim 1.0$ \\
\hline 耐薬 品 性 & $0-14$ & $0-14$ & $0-14$ \\
\hline 捕捉 イオン & カチオン全般 & 重 金属 類 & アニオン全般 \\
\hline 寸 $(\mathrm{mm})$ 法 & $47 \phi$ (標 準) & $47 \phi$ (標 潐) & $47 \phi$ (標 準) \\
\hline
\end{tabular}

注) Expapier は住友化学工業㑣)の商品名

表 $3 \cdot 1 \cdot 7$ 無機纃維紙の強度に及ぼすバインダーの効果 ${ }^{17)}$

\begin{tabular}{|c|c|c|}
\hline バインダー 種類 & 破 $\underset{\mathrm{kg} / \mathrm{cm}^{2}}{\text { 裂強 }}$ & $\begin{array}{c}\text { 引張 } \\
\mathrm{kg}\end{array}$ \\
\hline ユリア樹脂エマルジョン & 0.26 & 1.43 \\
\hline 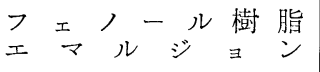 & 0.61 & 2.06 \\
\hline $\mathrm{S} B \mathrm{~B}$ ラテックス & 0.53 & 2.55 \\
\hline 塩ビラテックス & 0.65 & 3.10 \\
\hline 澱粉 & 0.72 & 4.25 \\
\hline アクリル 系 樹 脂 & 1.03 & 4.68 \\
\hline
\end{tabular}

注） 1 纎維 アルミノシリケート 100\%

2 バインダー添加（対綫維）

無機系 $\quad 30 \mathrm{Wt} \%$

3 紙料調整法

解繊濃度 $1 \%$ スラリー（実験用パルパー）

定着処理 高分子㠜集剤（カチオン,アニオン）

4 抄紙 坪量 $250 \mathrm{~g} / \mathrm{m}^{2}$, シート化

5 乾燥 プレス压 $2.5 \mathrm{~kg} / \mathrm{m}^{2}, 130^{\circ} \mathrm{C}$ 
定紙，殺菌/消毒紙，動物忌避／誘引紙など「対生物機能紙」も 出現しつつある16).

しかしながら，これらの素材は天然䋐維と異なり，いずれる親 水性に欠け，極めて「抄紙適性」が覀いものである。また，天然

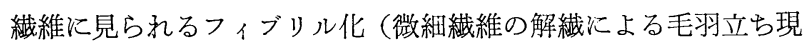
象）がなく, 繊維間の結合が弱い. 従って, 何らかのバインダー

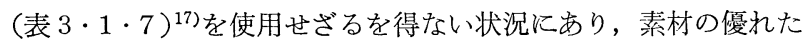
機能を阻害している.

\section{$3 \cdot 1 \cdot 1$ 具 体 例}

ここでは，著者らが関与したものについて例示することにする。

(1) 活性炭素繊維による野菜/果実の鮮度保持シート ${ }^{18)}$

最近, 野菜／果実の鮮度が劣化する原因として, エチレンガス の影響が指摘され, エチレンガスを吸着除去すると, 鮮度保持に 効果があると言われている. 著者らは表 $3 \cdot 1 \cdot 5$ と類似の活性炭 素繊維を用いて，図 $3 \cdot 1 \cdot 1$ に示したようなシートを作成し，エ チレンガスの吸収効果を検討した。
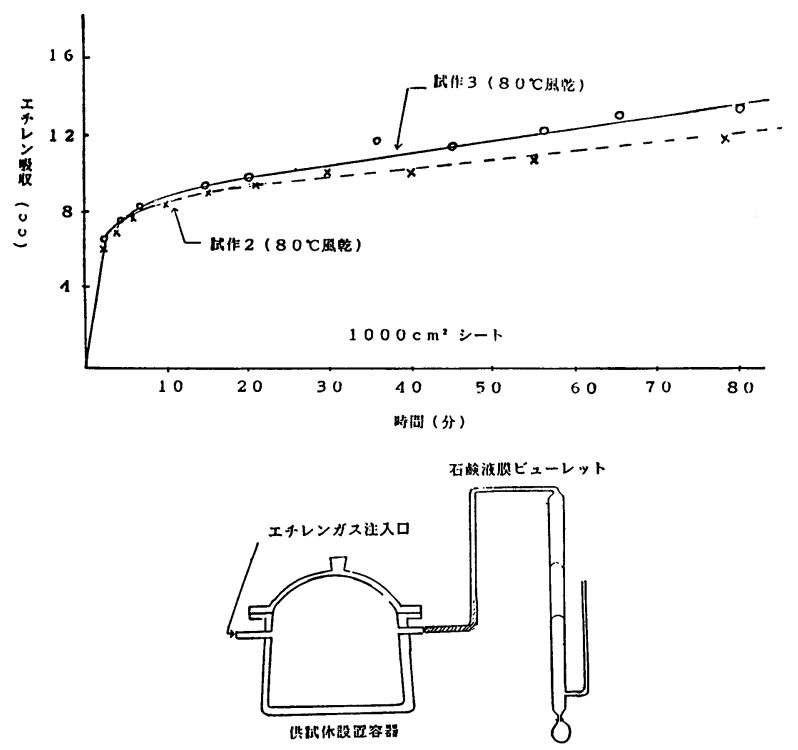

供 試 シート：サンドウィチ構造

表 層 部: $112-117 \mathrm{~g} / \mathrm{m}^{2}$ 活性炭䋐維部 : $18 \mathrm{~g} / \mathrm{m}^{2}$

活性炭繊維の処理 : 臭素酸カリウム $10-15 \mathrm{wt} \%$

(0.5mol 硫酸) 液を用い, 䋐維の 20 倍量に浸潰 $\left(60^{\circ} \mathrm{C} 30\right.$ 分)

紙力 增 強：3-5\% PVA 緎維 (対原料) を混抄 図 $3 \cdot 1 \cdot 1$ 活性炭素䋐維紙のエチレンガス吸収 果笑鮮度保持紙
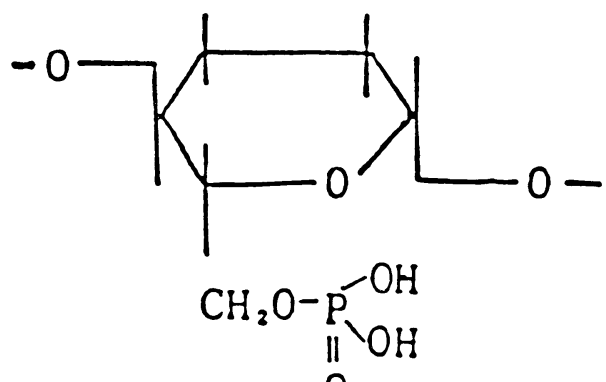

0

図3·1・2 リン酸エステル系イオン交換䋐維
（2）リン酸エステル系イオン交換繊維シートによる酒類の脱鉄 紙 ${ }^{19}$

図 $3 \cdot 1 \cdot 2$ のリン酸エステル系イオン交換䋐維紙を用いて酒類 の脱鉄に適用することを検討した。ビール（ライオン・スタウ 卜：福泉酒造）の鉄分は，ホップのタンニン物質と反応して貯蔵 中の着色劣化の原因となる．脱鉄に活性炭，キレート樹脂などを 使用すると，アミノ酸など香味成分も除去するために使用できな い. 結果を表 $3 \cdot 1 \cdot 8$ 亿示した. 表中の T-Fe は総鉄分を示す。 また，結合鉄はアミノ酸などと結合している鉄分を示している. 実験(1)から知られるように，リン酸セルロースは脱色（タートラ ジン：黄色染料）には作用せず，脱鉄のみに作用することがわか る.

（3）ニッケル・メッキ導電繊維（アクリロニトリル）紙による 静電気除去 ${ }^{20}$

図 3・1・3 亿示したような導電性纎維 ${ }^{21)}$ が製品化されている. この纎維を用いた一例を図 $3 \cdot 1 \cdot 4$ 亿示した，導電素材はシート

表 $3 \cdot 1 \cdot 8$ リン酸セルロースによる除鉄

試験（1）供試体：鉄塩（硫酸第 1 鉄アンモン：モール塩）十色 素 (タートラジン)

\begin{tabular}{c|c|c}
\hline P-セルロース & Fe $r / 10 \mathrm{ml}$ & 色素濃度 $\mathrm{T} \%$ \\
\hline $0 \mathrm{mg}$ & 2.50 & 53.00 \\
20 & 1.24 & 52.90 \\
70 & 0.67 & 52.20 \\
100 & 0.50 & 52.00 \\
200 & 0.24 & 51.40 \\
\hline
\end{tabular}

注）些験条件

1) $\mathrm{Fe}$ イオン定量 : $\alpha, \alpha$-dipiridil 試薬による比色法 $(520 \mathrm{~m} \mu)$

2) PH4 $1 / 10 \mathrm{~N}$ 酢酸・酢酸ソーダ緩衝液

3）リン酸セルロース:アベセルーP（安部川製紙） $10 \%$ $\mathrm{NaCl}$ 液ににて再生処理（イオン 交換容量 $2.0 \mathrm{meq} / \mathrm{gr}$ )

4）試験方法： $50 \mathrm{ml}$ の緩衝液に被吸着物を加穴，P-セル ロースを添加， 5 時間後に測定 (室温)

試験 （2）発泡酒（ライオンスタウト）の除鉄処理と効果

\begin{tabular}{|c|c|c|c|c|c|c|}
\hline 供 試 体 & $* \mathrm{~T}-\mathrm{Fe}$ & 経 & 0 & 20 & 60 & 120 \\
\hline \multirow{2}{*}{ 対照供試体 } & \multirow{2}{*}{$\begin{array}{c}\gamma / 10 \mathrm{ml} \\
0.97\end{array}$} & $\begin{array}{c}* * \text { 結合鉄 } \\
\gamma / 10 \mathrm{ml}\end{array}$ & 0.47 & 0.62 & 0.71 & 0.85 \\
\hline & & $\begin{array}{c}* * * \text { 色変化 } \\
\text { T1/T2 }\end{array}$ & 2.5 & 2.0 & 1.8 & 1.3 \\
\hline \multirow{2}{*}{ 処理供試体 } & \multirow{2}{*}{0.45} & $\begin{array}{c}\text { 結 合 鉄 } \\
\gamma / 10 \mathrm{ml}\end{array}$ & 0.33 & 0.43 & 0.43 & 0.45 \\
\hline & & $\begin{array}{l}\text { 色変化 } \\
\mathrm{T} 1 / \mathrm{T} 2\end{array}$ & 2.3 & 2.3 & 2.0 & 2.0 \\
\hline
\end{tabular}

一注）1）供試体：ライオンスタウト最終製品

2）処 理：フィルタープレス（現場）にP-七ルロース 紙を適用 $\left(100 \mathrm{~L} / 10 \mathrm{~m}^{2} \cdot \mathrm{sec}\right)$

3）* 灰化残分の総合分析

** PH4 緩衝液に供試体を稀积した後，イオン交換 樹脂処理して遊離鉄を除去した後の残留鉄

*** 日本醸造研究会提案（代表：小原）：分光比色法 $\mathrm{T} 1=\mathrm{T} 430-\mathrm{T} 470 \mathrm{~T} 2=\mathrm{T} 500-\mathrm{T} 600$ T*** は波長*** $\mathrm{m} \mu$ に打数透過率(\%) T1/T2 が大になれば赤色瀇色の 傾向を示す

4）供試体は一般製品と同様にびん詰後，通常倉庫に保管 ( 4 月〜 8 月) 


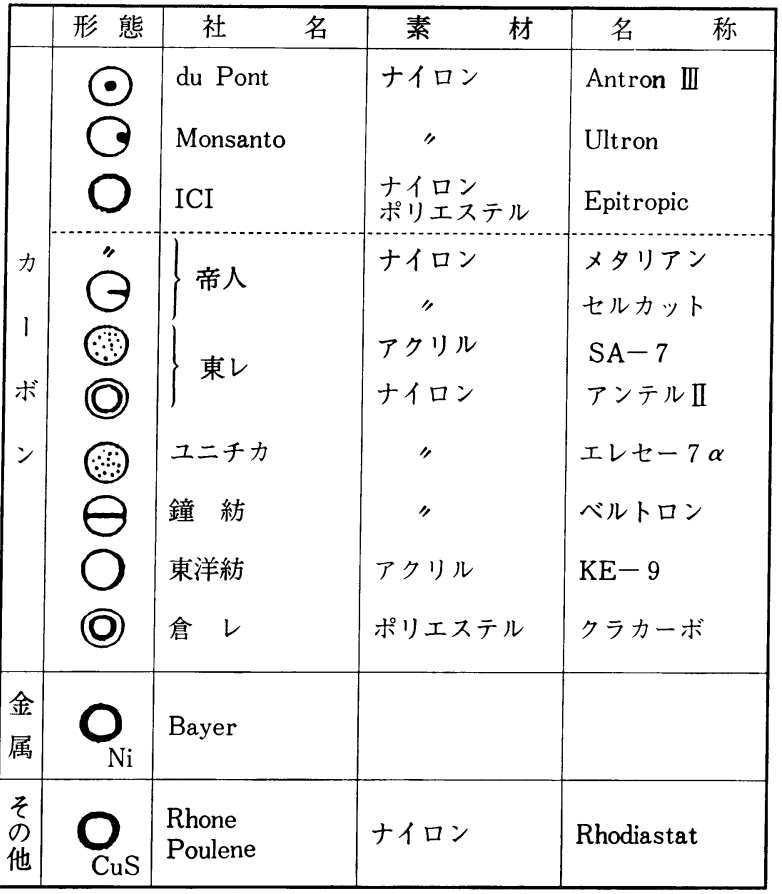

図3 $1 \cdot 3$ 導 電 性 緎 維 21$)$

の表面汇露出していなくてはならない，従って, 露出を阻害する ことなくシートに固着することが肝要であるが, 現在, 安価で有 効な手段を見いだしていず，シート表面の磨耗を防ぐ方法が今後 の課題である.

\section{$3 \cdot 2$ 構造を利用した機能}

ここで言う構造とは, シート自体の内部構造とシートを成形し て得られる構造を称している. 紙の特徴として「多孔性」が挙げ られ (図 $3 \cdot 2 \cdot 1)^{22)}$, これにより沪過, 分離に供されるフィル タ機能が発現する. $3 \cdot 1$ 項の素材と組又合わせて耐熱性, 而薬品 性のある多孔体が得られ, 従来紙と異なる用途が開かれる（表 $3 \cdot 2 \cdot 1)$.

また，シートを成形して構造体にして機能を付与する場合も多 い. 例えば，図 $3 \cdot 2 \cdot 2$ は交差する 2 枚の段ボール状の波状構造 体で多孔性シートを㣣む構造を一単位とし，このものを積層した 熱交換体である，交差する段ボール状の空隙に温度の異なる空気 を流し，多孔性シートを間㗝交換させようとするものである (表 $3 \cdot 2 \cdot 2)^{23)}$. また，図 $3 \cdot 2 \cdot 3$ は段ボール状の波状シートを 円盤状に巻き, 断面の空隙に通気することで, 空気を乾燥させよ うとするものである。この場合，耐薬品性抽よび耐熱性に優れた 無機繊維のシート物が適用され，臭化リチウムなど吸湿剮がシー トに含浸される場合も多い。

\section{$3 \cdot 2 \cdot 1$ 具 体 例}

(1) シート内部俩造に機能設計した油／水分離フィルタ24) 27) 紙の内部構造を利用した機能設計の例として, 多量の水に含ま れる少量の油を除去 (以下, 油水分離と言う) することを目的と したフィルタを紹介する.

油と水のように性質が相反する混合物が細い空隙を通過すると， 混在状態が不安定になり, 分離しやすい状態になる現象があり, 「細管コアレス (coalesce) 効果」と言われる．著者らはこの現象

静電気減衰曲線

（b）導電性䋐維 $1 \%$ アクリルエマルジョン

(a) 原紙 フルスケール $50 \mathrm{mV}$

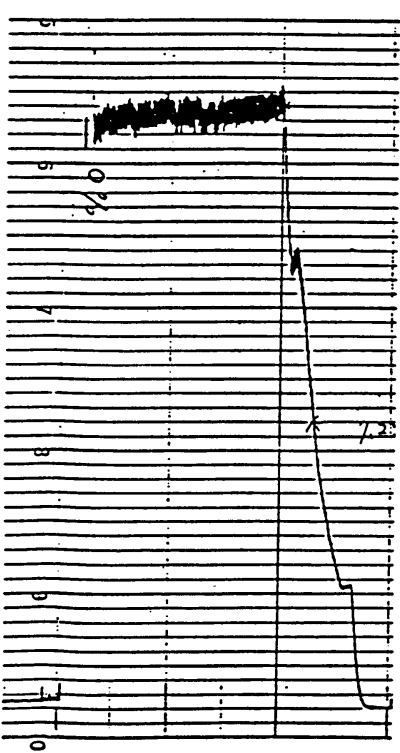
コーティング $\left(14 \mathrm{~g} / \mathrm{m}^{2}\right)$ フルスケール $20 \mathrm{mV}$

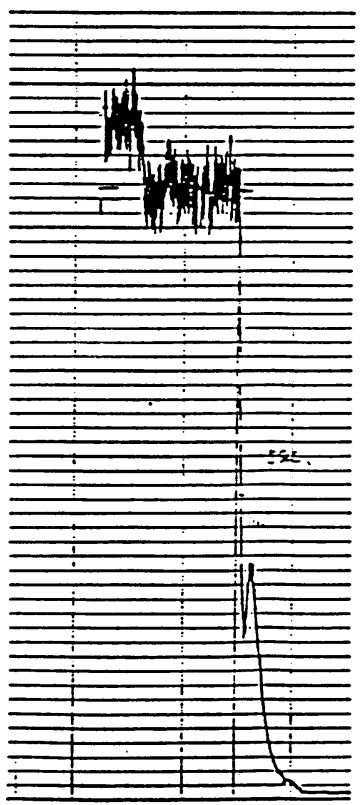

表面抵抗と静電気特性

\begin{tabular}{|c|c|c|c|c|c|}
\hline \multicolumn{2}{|c|}{ 試 } & 料 & $\begin{array}{c}\text { 表面抵抗 } \\
(\Omega)\end{array}$ & $\begin{array}{c}\text { 静電気帯電压 } \\
(\mathrm{V})\end{array}$ & $\begin{array}{c}\text { 帯電圧半減期 } \\
\text { (sec.) }\end{array}$ \\
\hline \multicolumn{2}{|c|}{ 原 } & 紙 & $10^{10}$ 以上 & 300 & 7.2 \\
\hline \multirow{4}{*}{$\begin{array}{l}\text { 導 } \\
\text { 電 } \\
\text { 性 } \\
\text { 緎 } \\
\text { 維 }\end{array}$} & 1 & $\%$ & $3.9 \times 10^{9}$ & 19 & 7.2 \\
\hline & 3 & $\%$ & $1.3 \times 10^{7}$ & 11 & - \\
\hline & 5 & $\%$ & $7.7 \times 10^{4}$ & 11 & - \\
\hline & 10 & $\%$ & $1,7 \times 10^{4}$ & 6 & - \\
\hline \multirow{4}{*}{$\begin{array}{l}\text { 趇 } \\
\text { 面 } \\
\text { 処 } \\
\text { 理 }\end{array}$} & 1 & $\%$ & $10^{10}$ 以上 & 23 & 1.5 \\
\hline & 3 & $\%$ & $10^{10}$ 以上 & 17 & - \\
\hline & 5 & $\%$ & $10^{10}$ 以上 & 20 & - \\
\hline & 10 & $\%$ & $4.8 \times 10^{9}$ & 20 & - \\
\hline
\end{tabular}

※ アクリル・エマルジョン $14 \mathrm{~g} / \mathrm{m}^{2}$ 塗付

NUKP $\quad \operatorname{csf} 500 \mathrm{ml}$

アクリル繊維 $3.5 \mathrm{~mm}$ カット

紙力增強剤 SWP. PVA 繊維

図3 $3 \cdot 1 \cdot 4$ 導電性緎維紙の特性 ${ }^{20)}$

と紙の多孔性に着目して, この効果を積極的に作動させる機能を 紙層内に設けようとした。

図 $3 \cdot 2 \cdot 4$ に示したように，「集油一粗粒化一自力分離」作用 をする機構を想定した。 そのためには, 油捕集作用と捕集油離脱 作用を共存させる. 微細油は油捕集作用で捕集されて粗大化し, 隣接する油離脱作用を受けて，粗大油滴となって自力で浮上する. 油捕集はポリオレフィン系合成繊維などの親油性を利用した．離 脱はコンニャク，寒天など含水ゲルが全く油を付着しないことに 着目して，シート内に含水ゲルを設けて構成した。具体例を表 $3 \cdot 2 \cdot 3$ に示した。このよ5にして得られたシートを図 $3 \cdot 2 \cdot 5$ の方法で, 水溶性切削剂液に混入した乳化油に適用したときの粗 


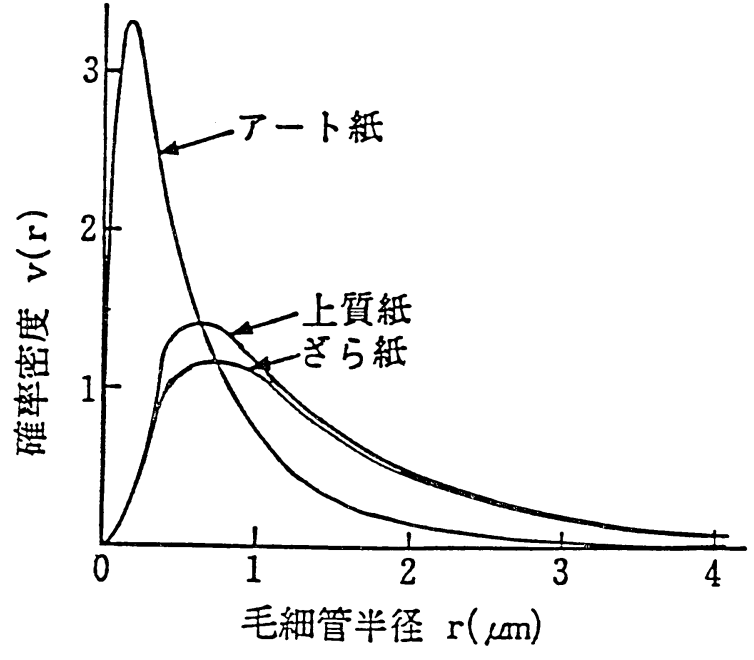

図 $3 \cdot 2 \cdot 1$ 紙の気孔量分布 ${ }^{22}$

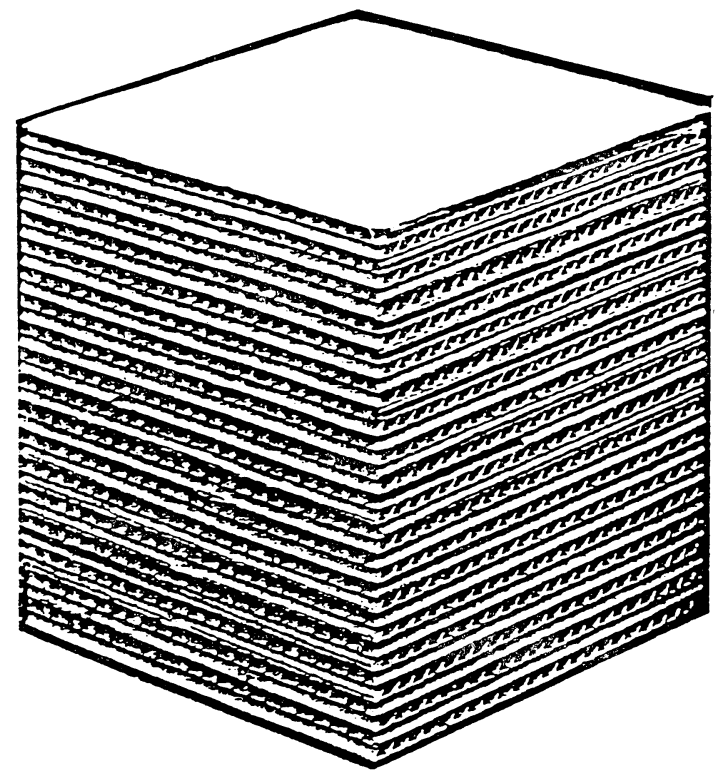

図 $3 \cdot 2 \cdot 2$ 熱交換体としてのハニカム構造体

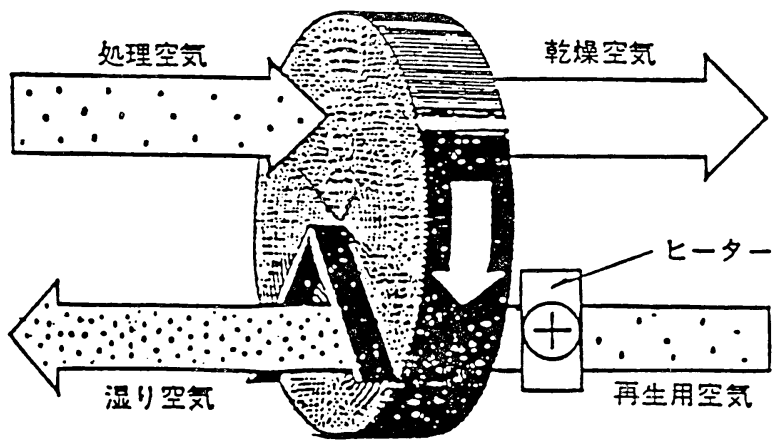

図3 $2 \cdot 3$ 除湿用ハニカム構造体
表 $3 \cdot 2 \cdot 1$ 七ラミック多孔体の応用例

\begin{tabular}{|c|c|c|c|c|}
\hline 機能 & 分 離 & 分 散 & 吸 収 & 接 触 \\
\hline 特長 & 高沪過特性 & 均一発泡 & $\begin{array}{l}\text { 高空 } \\
\text { 献き率 }\end{array}$ & 比表面積大 \\
\hline $\begin{array}{l}\text { セラミックフィル } \\
\text { ターエンメント }\end{array}$ & $\begin{array}{l}\text { 高温集鹿 } \\
\text { ミスト分離 } \\
\text { 電解隔膜 } \\
\text { プレコート } \\
\text { 沪過 }\end{array}$ & $\begin{array}{l}\text { 散気板 } \\
\text { 分散板 }\end{array}$ & 吸音板 & \\
\hline
\end{tabular}

セラミックハニカ 高温集糜 整流格子 断熱材 触媒担体 ムエレメント

熱交換体

充てん体

表 $3 \cdot 2 \cdot 2$ 紙の気孔を利用した熱交換機ロスナイの特長 ${ }^{23)}$

\begin{tabular}{|c|c|c|c|c|c|}
\hline & & & $\begin{array}{l}\text { ㅁㅈ } \\
\text { ナイ }\end{array}$ & 顕換機 & 換気般扇 \\
\hline \multirow{2}{*}{$\begin{array}{c}\text { 熱交換率表 } \\
(\%)\end{array}$} & \multirow{2}{*}{\multicolumn{2}{|c|}{$\begin{array}{lll}\text { 温 } & \text { （顕熱） } \\
\text { 湿 度 } & \text { (潜熱) }\end{array}$}} & 75 & 75 & 0 \\
\hline & & & 65 & 0 & 0 \\
\hline \multirow{8}{*}{$\begin{array}{l}\text { 熱交換後の } \\
\text { 換気の温度 } \\
\text { と湿度 }\end{array}$} & \multirow{4}{*}{ 夏 } & 室内 外気 & & & \\
\hline & & 乾球温度 ${ }^{\circ} \mathrm{C} 2632$ & 27.5 & 27.5 & 32 \\
\hline & & 相対湿度\% $50 \quad 70$ & 62 & 91 & 70 \\
\hline & & 回収全熱量 $\mathrm{kcal} / \mathrm{kg}$ & 636 & 132 & 0 \\
\hline & \multirow{4}{*}{ 冬 } & 室内 外気 & & & \\
\hline & & 乾球温度 ${ }^{\circ} \mathrm{C} 20 \quad 0$ & 15 & 15 & 0 \\
\hline & & 相対湿度 \% 5050 & 52 & 19 & 50 \\
\hline & & 回収全熱量 $\mathrm{kcal} / \mathrm{kg}$ & 696 & 432 & 0 \\
\hline
\end{tabular}

換気量 $100 \mathrm{~m}^{3} / \mathrm{h}$ 空気比重 $\gamma=1.2 \mathrm{~kg} / \mathrm{m}^{3}$

注）ロスナイ : 三菱電機㑣製品名

表 $3 \cdot 2 \cdot 3$ 油水分離フィルタ構成 (例)

\begin{tabular}{|c|c|c|}
\hline \multicolumn{2}{|c|}{ 原料 } & 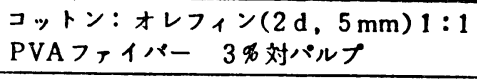 \\
\hline \multirow[t]{2}{*}{ 抄 } & 林 & 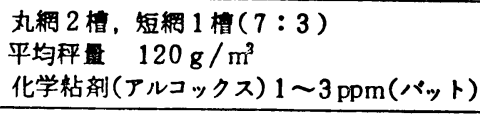 \\
\hline & 耐水性付与 & 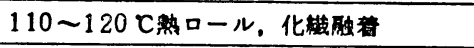 \\
\hline \multirow{3}{*}{ 加工 } & $\begin{array}{l}\text { 耐水, 耐油 } \\
\text { 性强化 }\end{array}$ & 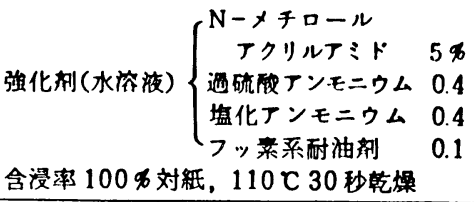 \\
\hline & $\begin{array}{l}\text { 油水分踓機 } \\
\text { 能 }\end{array}$ & 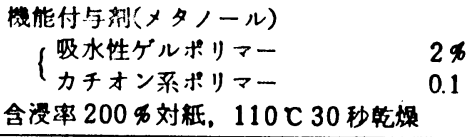 \\
\hline & $\begin{array}{l}\text { エレメント } \\
\text { 化工程 }\end{array}$ & $140^{\circ} \sim 150 \mathrm{C}$ 加熱 \\
\hline
\end{tabular}

注） 1 吸水性ゲルポリマーは既成ポリマーであり，親 水性溶媒にコロイド状に分散可能。

2 耐水, 耐油性強化の処法は, 紙層内重縮合反応 による（機能紙研究会誌 6 , Oct. 9 (1967) 参 照）。

3 含浸処理は生産規模の含浸機使用。

4 エレメント化工程で型付加工 (ひだ付加工) が 行われる。 


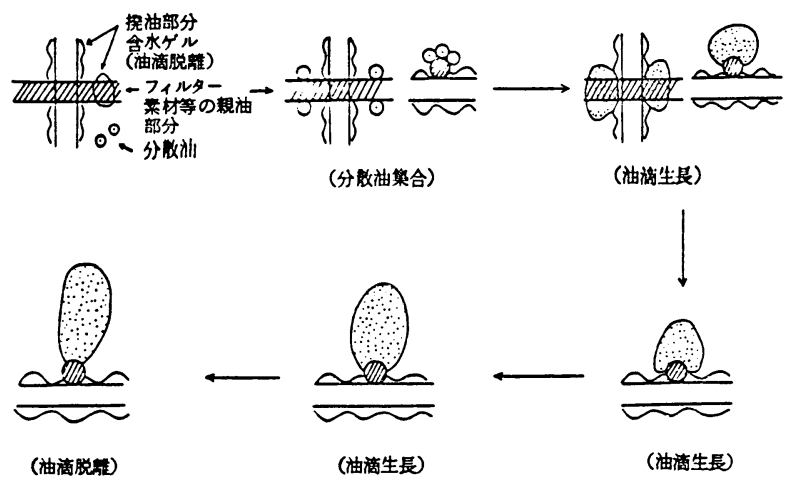

図 $3 \cdot 2 \cdot 4$ 油水分離機能のモデル

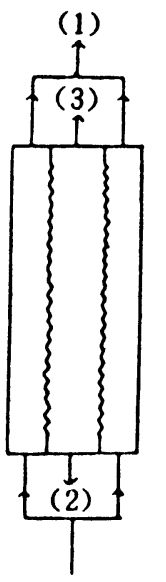

（0）原液

(1) フィルター

表 層 液

(2) 滤 過 液

（3）フィルター通過

浮 上 油

有効滤過面積 $24 \times 9 \times 2 \mathrm{~cm}^{2}$

供 試 原 液

軽スピンドル油/グライトン 1300

供試液量 $10 l$

(0)

図 $3 \cdot 2 \cdot 5$ 微細分散油の粗粒化実験方法

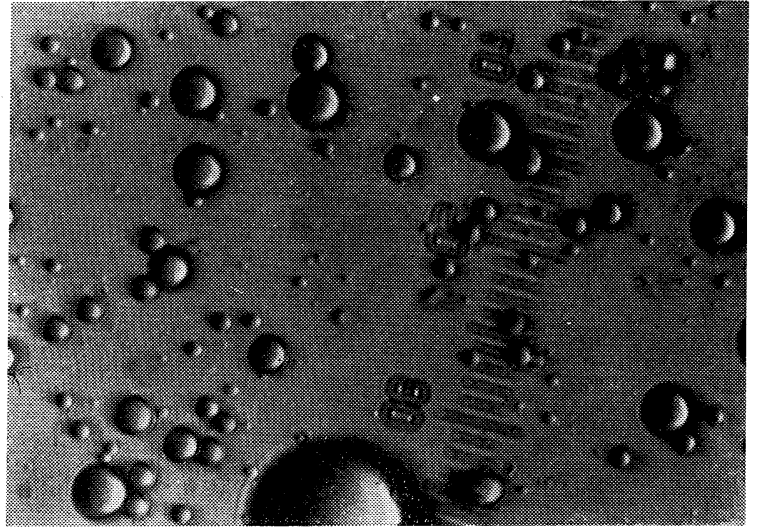

原油の油粘（最小目盛 $2.5 \mu \mathrm{m}$ )

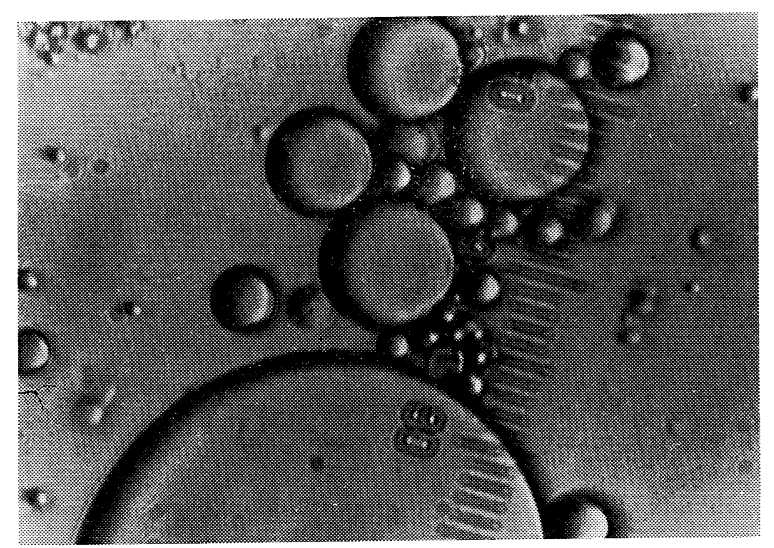

シート通過（全通方式）添の油粒（最小目盛 $2.5 \mu \mathrm{m}$ ) 写真 $3 \cdot 2 \cdot 1$ 微細分散油の粗粒効果

表 $3 \cdot 2 \cdot 4$ 脳 $3 \cdot 2 \cdot 5$ の方法による結果

\begin{tabular}{|c|c|c|c|c|c|c|c|c|c|}
\hline \multirow{2}{*}{ 7ィルター } & \multirow{2}{*}{ 週方式 } & \multirow{2}{*}{$\begin{array}{l}\text { 㳚压力 } \\
\mathrm{kg} / \mathrm{cm}^{2}\end{array}$} & \multirow{2}{*}{ 過条件 l／分 } & \multirow{2}{*}{ 期若体区分 } & \multicolumn{5}{|c|}{ 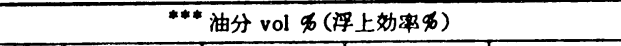 } \\
\hline & & & & & 0分 & 10 分 & 30 分 & 60 分 & 90 分 \\
\hline \multirow[t]{2}{*}{ フィルター } & 分流方式 & $0.2 \sim 0.3$ & 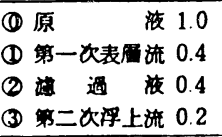 & 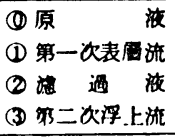 & $\begin{array}{l}1.50 \\
1.25 \\
1.50 \\
1.75 \\
\end{array}$ & $\begin{array}{l}0.75(50.0) \\
0.75(40.0) \\
0.60(60.0) \\
0.75(57.1) \\
\end{array}$ & $\begin{array}{l}0.75(50.0) \\
0.75(40.0) \\
0.25(83.3) \\
0.50(71.4) \\
\end{array}$ & $\begin{array}{l}0.75(50.0) \\
0.50(60.0) \\
0.35(76.7) \\
0.50(71.4) \\
\end{array}$ & $\begin{array}{l}0.50(66.7) \\
0.50(60.0) \\
0.20(86.7) \\
0.20(88.6) \\
\end{array}$ \\
\hline & 全通方式 & $0.5 \sim 0.7$ & 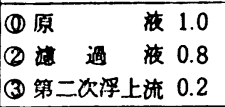 & $\begin{array}{l}\text { (1) 原 } \\
\text { (2) 過 液 } \\
\text { (3) 第二次浮上流 }\end{array}$ & $\begin{array}{l}1.00 \\
1.25 \\
1.25 \\
\end{array}$ & $\begin{array}{l}1.00(0) \\
0.80(36.0) \\
0.50(60.0)\end{array}$ & $\begin{array}{l}0.75(25.0) \\
0.40(68.0) \\
0.30(76.0) \\
\end{array}$ & $\begin{array}{l}0.50(50.0) \\
0.25(80.0) \\
0.15(88.0) \\
\end{array}$ & \begin{tabular}{|l}
$0.25(75.0)$ \\
$0.25(80.0)$ \\
$0.25(80.0)$ \\
\end{tabular} \\
\hline \multirow[t]{2}{*}{ 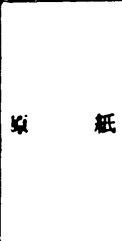 } & 分流方式 & $1.2 *$ & 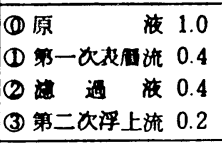 & 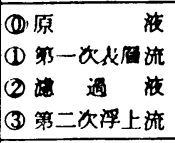 & \begin{tabular}{|l|}
1.00 \\
1.15 \\
1.00 \\
1.50 \\
\end{tabular} & $\begin{array}{l}0.75(25.0) \\
0.75(34.8) \\
0.85(15.0) \\
0.55(43.3) \\
\end{array}$ & $\begin{array}{l}0.95(15.0) \\
0.75(34.8) \\
0.75(25.0) \\
0.85(43.3) \\
\end{array}$ & $\begin{array}{l}0.70(30.0) \\
0.75(34.8) \\
0.75(25.0) \\
0.50(66.7) \\
\end{array}$ & \begin{tabular}{|cc}
0.50 & $(50.0)$ \\
- & - \\
0.50 & $(50.0)$ \\
0.40 & $(73.3)$ \\
\end{tabular} \\
\hline & 全通方式 & $1.5 \sim 1.8 * *$ & $\begin{array}{lll}\text { (1) 原 } & \text { 波 } & 0.6 \\
\text { (2) 遍 } & \text { 波 } 0.4 \\
\text { (3) 第二次浮上流 } & 0.2\end{array}$ & 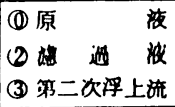 & $\begin{array}{l}1.00 \\
1.30 \\
1.25\end{array}$ & $\begin{array}{l}1.00(0) \\
1.25(3.8) \\
1.25(0)\end{array}$ & $\begin{array}{l}0.95(5.0) \\
1.00(23.1) \\
1.00(20.0)\end{array}$ & $\begin{array}{l}0.80(20.0) \\
0.80(38.5) \\
1.00(20.0)\end{array}$ & $\begin{array}{l}0.60(40.0) \\
0.75(50.0) \\
0.75(40.0)\end{array}$ \\
\hline
\end{tabular}

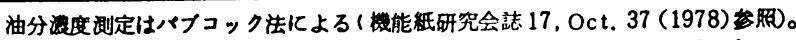

*段定条件を椎持するのに，初の 5 分間て $0.2 \mathrm{~kg} / \mathrm{cm}^{2}$ 加ら $0.5 \mathrm{~kg} / \mathrm{cm}^{2}$ に上㫒，さらに 3 分間て $1.2 \mathrm{~kg} / \mathrm{cm}^{2}$ に上㫒した。

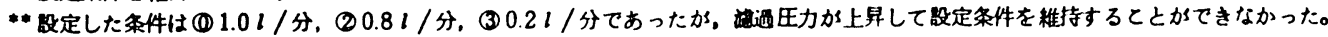

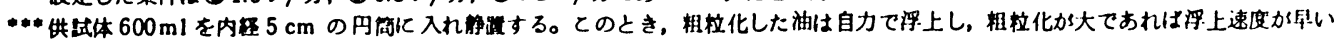

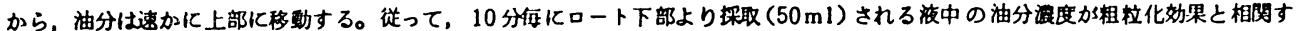

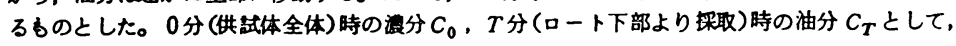

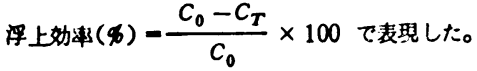




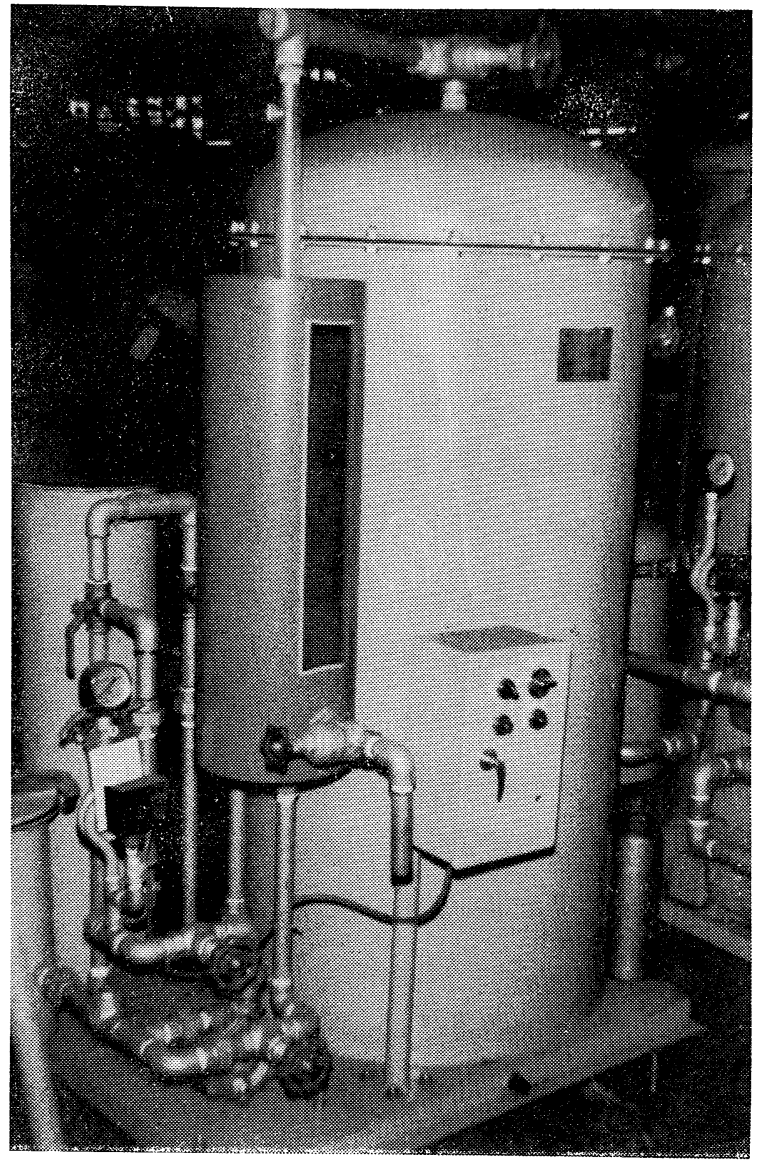

写真 $3 \cdot 2 \cdot 2$ 油水分離フィルタ装着装置 $(\text { 吴稼働装置 })^{29}$

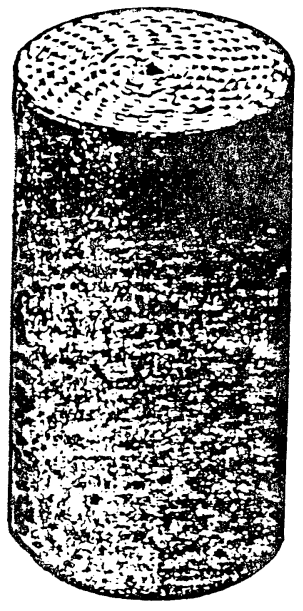

正面斜視図

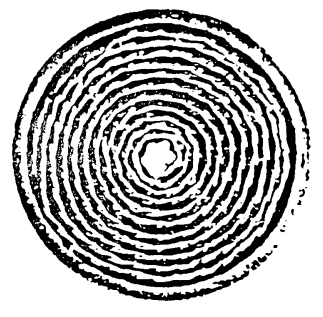

上面図

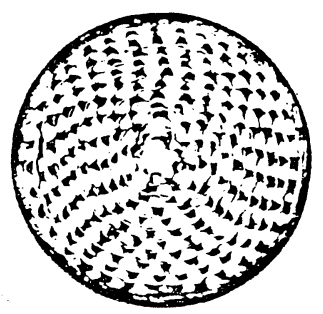

底面図

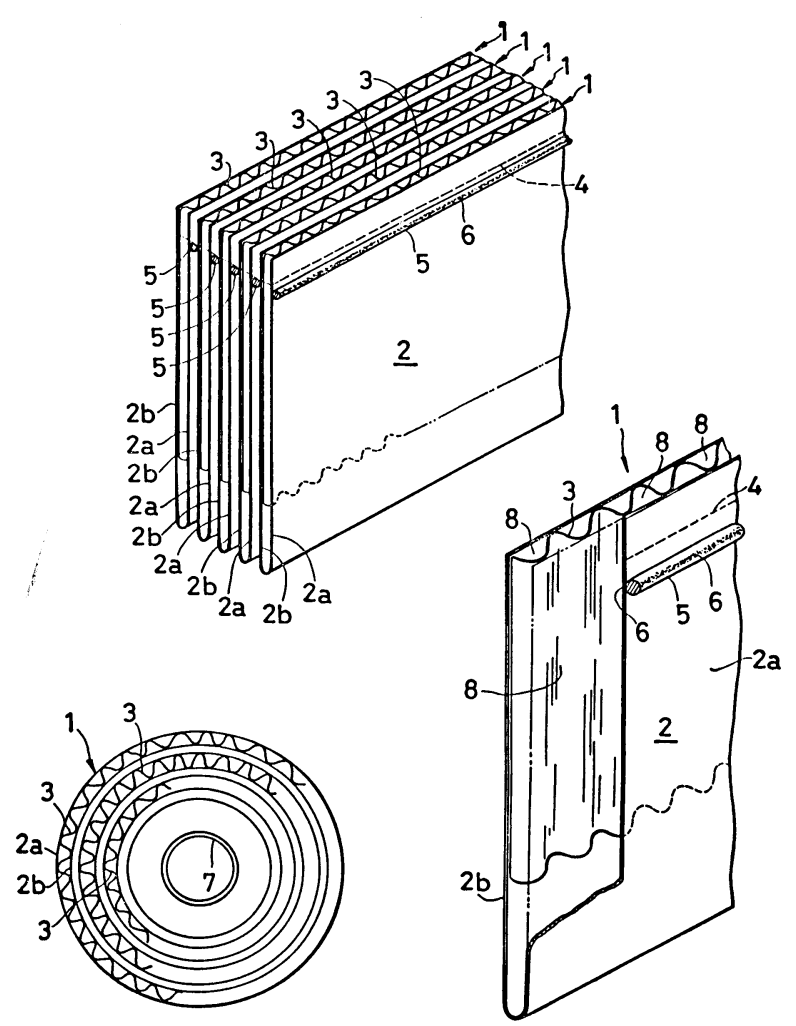

図 $3 \cdot 2 \cdot 7$ 自動車用然料フィルタ ${ }^{30}$

粒化効果 (上記したように, 沪過機能ではなく細管コアレス効果 を重視している）を表 $3 \cdot 2 \cdot 4$ に，処理前後の油の粗粒化状沉を 写真 $3 \cdot 2 \cdot 1$ に示した。 このものは既に赛用化され，図 $3 \cdot 2 \cdot 6$ に示した段ボール波状構造を利用した構造体 ${ }^{28}$ にして, 写真 3 . $2 \cdot 2$ の如き装置 ${ }^{29}$ 浽着されて, 金属表面処理（メッキ, 塗装 など）の前工程の洗浄液の清净化に使用されている.

(2) 構造化による自動車燃料用フィルタ30)

最近, 自動車然料供給システムが, 従来のキャブレータ方式に 替り，噴射方式が採用されるようになった，その理由は停車，発 進, 高/低速時の然料供給をコンピュータ制御で行う方式が採用 されるようになったからである.これに伴って, 燃料用フィルタ む従来の「蛇腹型」に替るものが要求され, 最小形状で最大沪過 面積になるように設計されたものが考案された。藷者らも, 図 $3 \cdot 2 \cdot 7$ 亿示した構造を有するフィルタを考案し, その性能を試 験中である.この例は, 需要との関係から設計された「機能」で あり，特別の材料を用いなくとも「機能」設定が可能であること を示している。

\section{$3 \cdot 3$ 変体加工特性による機能}

ここで言う変体加工特性とは, 本来の「紙」が特別の処理によ り全く異質な性質に変り, 加工前の性状からは予想されない別用 途に適用されることを意味する。例えば，施ユウ紲 ${ }^{31}$ なるものが ある. 陶磁器のユウ薬に相当する成分と繊維を混抄して得られる シート物であり, このものを素焼の陶磁器に貼って焼成すること で，ユウ掛けと同じ效果を狙ったものである，焼成前は紙状シー トであり, 菼成処理の後ではガラス質化して, 処理前の性状とは 全く異質な性状に変体して「機能」を発現する例である。この分

図3 $2 \cdot 2 \cdot 6$ 油水分離フィルタの害用形状 ${ }^{28)}$ 
表 $3 \cdot 3 \cdot 1$ ペーパー・セラミックの原紙組成と焼成結果

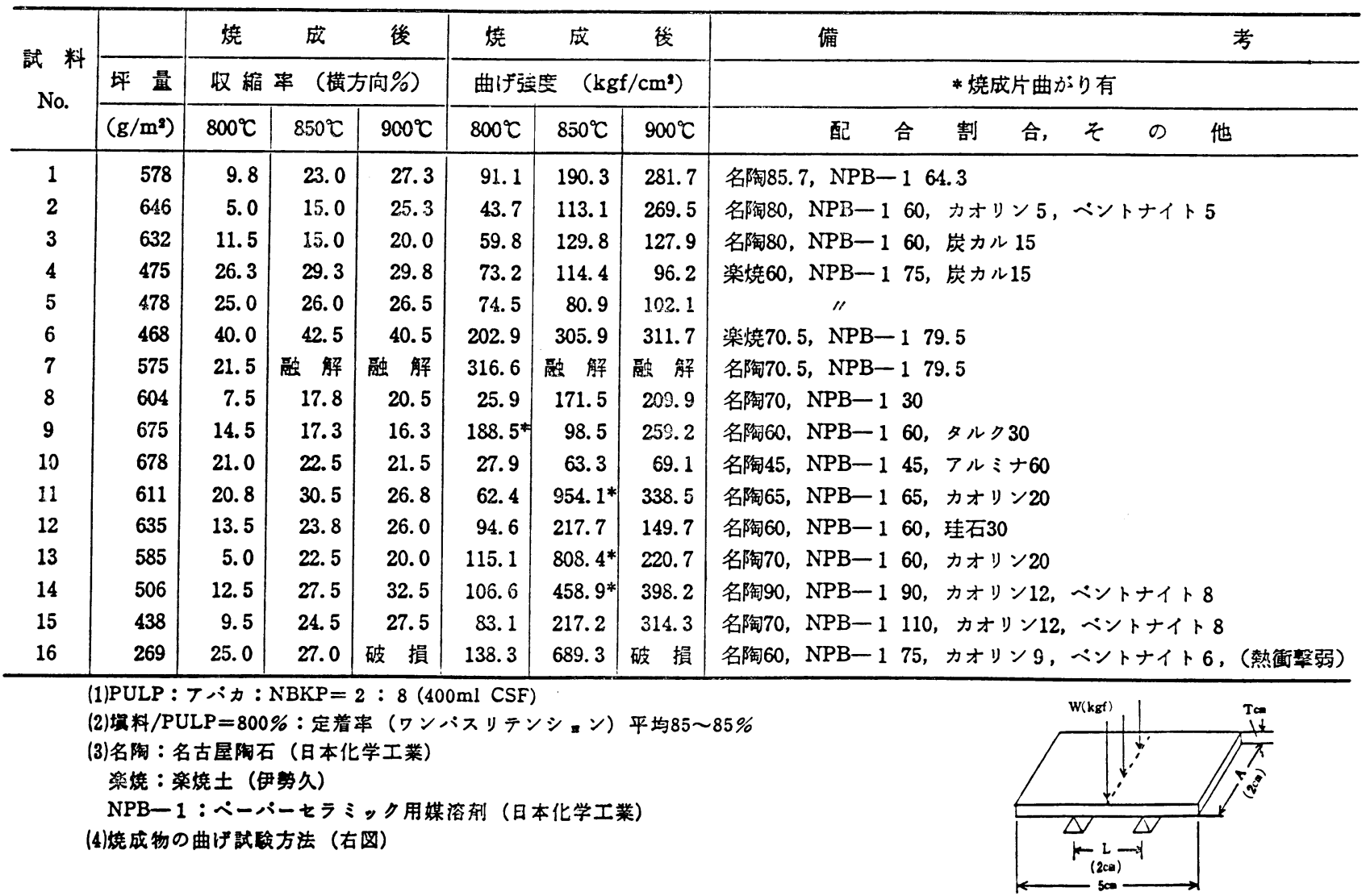

$F=\frac{3 W^{2} \mathrm{~L}}{2 \mathrm{~A}^{2}}(\mathbf{k g t} / \mathbf{\omega r})$

表 $3 \cdot 3 \cdot 2$ ペーパー・セラミックの期待される用途例

A）資材分野別用途

\begin{tabular}{|c|c|c|}
\hline 分 & 処 & ま た は 用 途 \\
\hline 複 合 資材 & $\begin{array}{l}\text { プラスチッククなど合成樹脂, カー } \\
\text { ボン:ガラスなどの繊維板, 金 } \\
\text { 属, と複合化 }\end{array}$ & $\begin{array}{l}\text { 断熱・耐久性建材, 電気部品の保護材, 加熱部分の防護壁, 金属部品 } \\
\text { の表面被覆材, 輸送機械の耐久性防護壁材, 耐薬品性保護資材, ク } \\
\text { 乎板 }\end{array}$ \\
\hline 被 覆 資 & 被覆焼結，焼結ライニング & 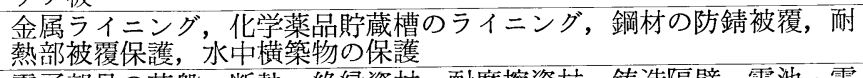 \\
\hline 耐久. 安定資材 & 焼成処理 & 電子部品の基盤, 断熱 ·絶縁資材, 耐摩擦資材, 鋳造隔壁, 電池·電 \\
\hline 横 造 化 資 材 & 成形加工後の燃成 & $\begin{array}{l}\text { 営置の允横造体, 䕊熱材, 触媒担体, 酵素固定化担体, 活性污泥処理 } \\
\end{array}$ \\
\hline 美 装 化 陶 磁器 & 成形加工後の焼成 & $\begin{array}{l}\text { 陶磁器板, 美装タイル, 壁材, モザイック材, 照明器具のシェード, } \\
\text { 装飾壁材 }\end{array}$ \\
\hline ホビー・陶芸用資材 & $\begin{array}{l}\text { 貼弇, 型付, 打拻, 成形, 折量, } \\
\text { など加工後の焼成 }\end{array}$ & 陶板画，折紙，装飾具など造形資材 \\
\hline \multicolumn{3}{|l|}{ B) 特性別用途 } \\
\hline 特 & 処 & 製品または用途 \\
\hline 多 孔 質 性 & 焼成温度の変化で調整が可能 & 液·気体吸着体, 接触反忍媒体, 充填材, 耐久性万化休, 隔壁材 \\
\hline 耐 熱, 耐 薬 品 性 & $\begin{array}{l}\text { 焼成後は陶磁器化する．焼成温度 } \\
\text { 変化で調整が可能 }\end{array}$ & 蓄熱材，熱交換体，熱板，耐熱絶縁体，化学反灾媒休 \\
\hline 成 形 加 工 性 & $\begin{array}{l}\text { コルゲート, エンボス, 折瞢, 打 } \\
\text { 抜, 貼合, 紙管, 製㻁, プレス成形 }\end{array}$ & $\begin{array}{l}\text { 横造化セラミック, 電子オープン・トレー, 漁礁構体, 生物活性浄化 } \\
\text { 处理の充填材, 陶芸 }\end{array}$ \\
\hline 薄層焼結性执よび融結性 & 自己接合, 異種素材との接合 & $\begin{array}{l}\text { 素焼セラシック体の表面処理，他の陶磁体との融結接合材，金属焼付 } \\
\text { イニシグ, 美装化材 }\end{array}$ \\
\hline
\end{tabular}


表 $3 \cdot 3 \cdot 3$ ペーパー・七ラミックの主な技術的課題

\begin{tabular}{|c|c|c|c|}
\hline 技 & 分 & 問 & 子 想される \\
\hline \multirow[t]{4}{*}{$\begin{array}{l}\text { セミッッ } \\
\text { 化基材 }\end{array}$} & 原 & 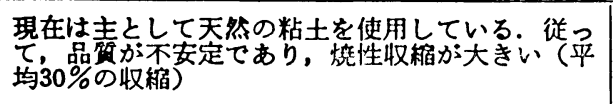 & 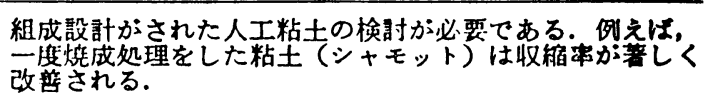 \\
\hline & \multirow[t]{3}{*}{ 副 $\quad$ 原 $\quad$ 料 } & 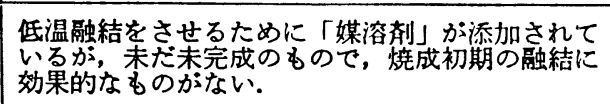 & 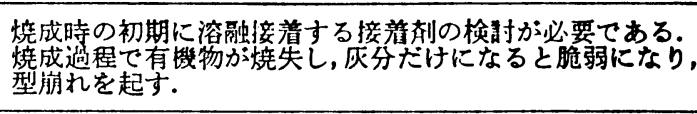 \\
\hline & & 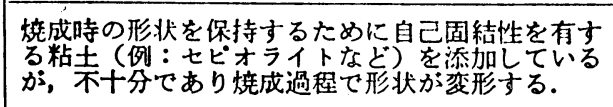 & 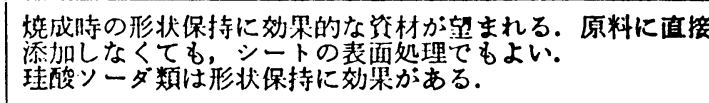 \\
\hline & & 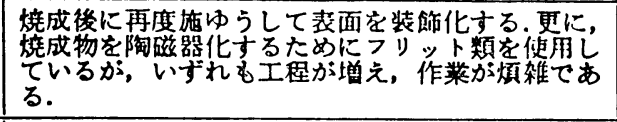 & 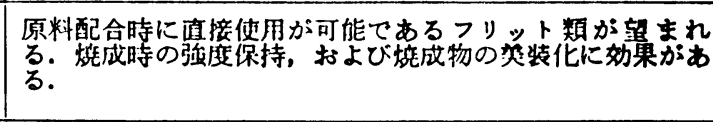 \\
\hline \multirow[t]{5}{*}{ シート化資 } & 維 & 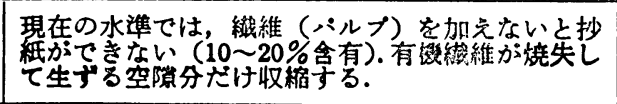 & 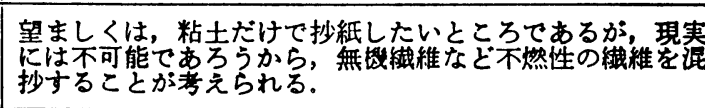 \\
\hline & 者 & 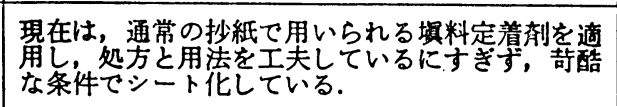 & 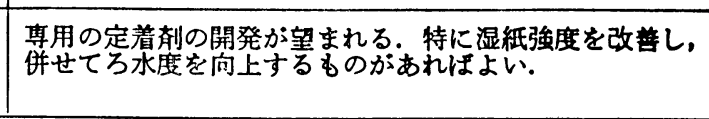 \\
\hline & 紙力堌強刹 & 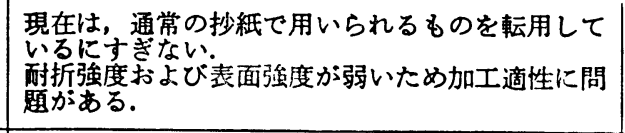 & 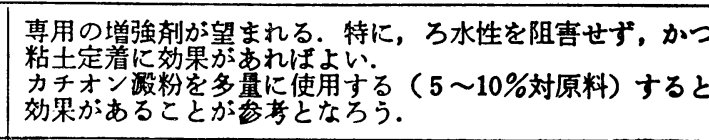 \\
\hline & 粉落ち防止 & 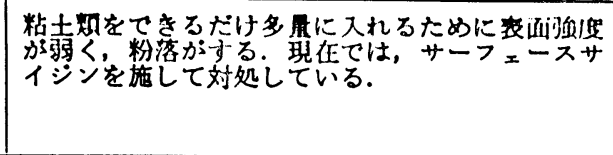 & 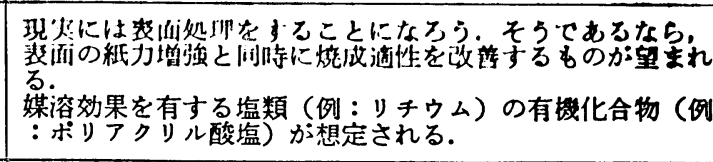 \\
\hline & 祋性の付与 & 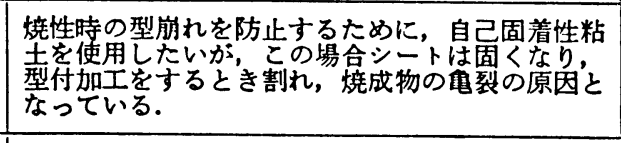 & 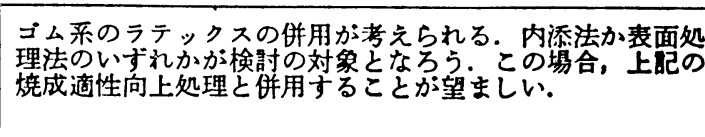 \\
\hline \multirow[t]{3}{*}{ 抄程方法 } & 紙 & 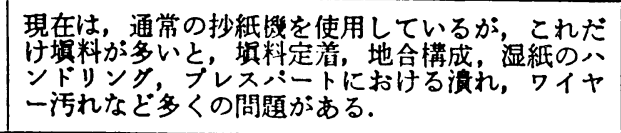 & 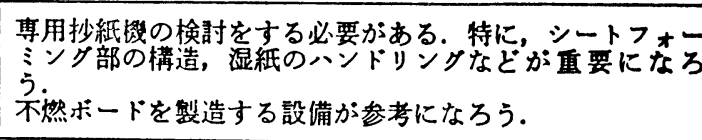 \\
\hline & 原 料 調 成 & 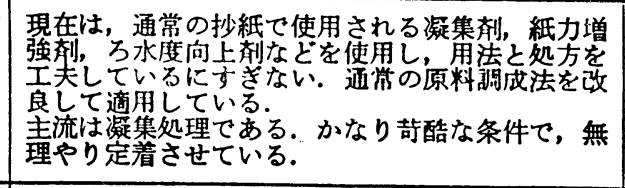 & 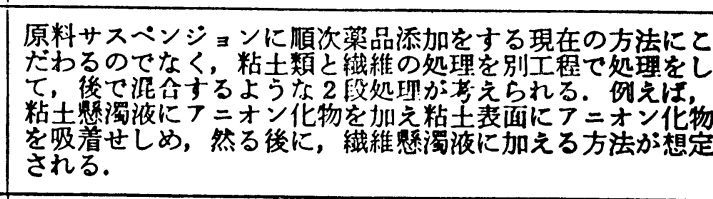 \\
\hline & 料愉送方法 & 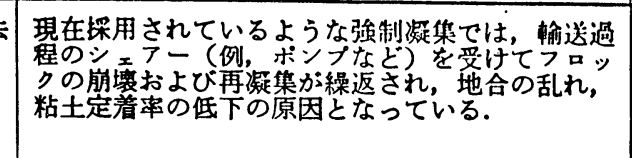 & 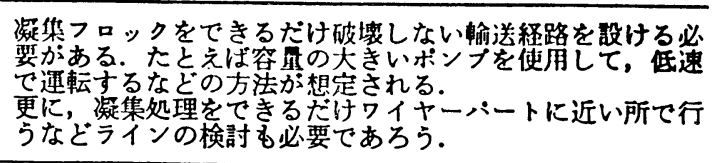 \\
\hline \multirow[t]{2}{*}{ 名筷向上 } & $\begin{array}{l}\text { 成収綟虫の低 } \\
\text { おおよび安定化 }\end{array}$ & 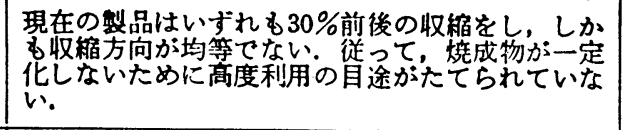 & 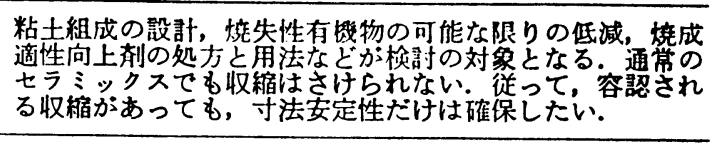 \\
\hline & $\begin{array}{l}\text { 㜔成温度に対子 } \\
\text { 万嘅 }\end{array}$ & 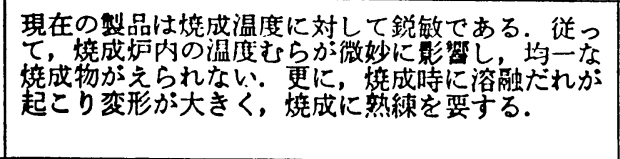 & 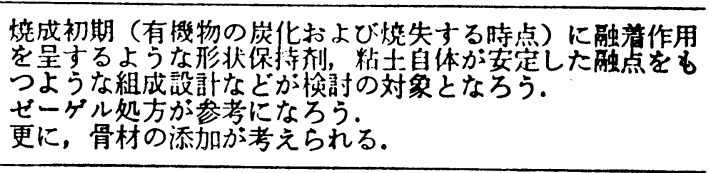 \\
\hline \multirow[t]{2}{*}{ その他の付 } & 理的処理 & 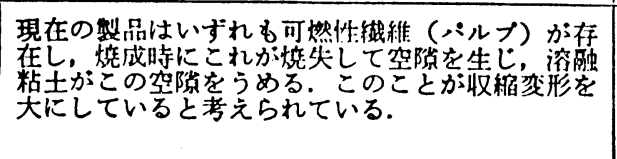 & 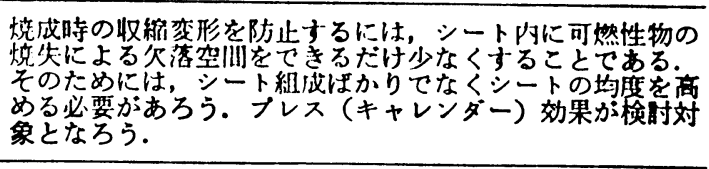 \\
\hline & 塑 & 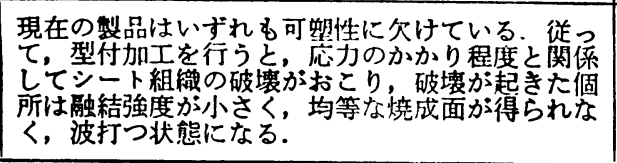 & 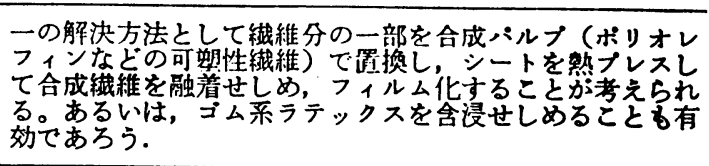 \\
\hline
\end{tabular}


野は末だ開発途上であり，著者の知るものは少ない，今後，金属 のライニング, 路面修復, 異種素材の溶融接合などを目的とした シート物が開発されると思われる。

\section{$\mathbf{3} \cdot \mathbf{3} \cdot \mathbf{1}$ 具 体 例}

(1) 低温焼結性填料高含有紙 (ペーパー・七ラミック $)^{32 ~ 34)}$

従来紙と異なり，瀻維分を出来る限り僅少に抑えて，大部分を 焼結性粘土にしたシートである。このものを成形した後，800〜 $900^{\circ} \mathrm{C}$ で焼成すれば，焼成前の形状を保持して陶磁器化する特徵 を有している．焼成物の特性は基材粘土に影響される．混入した 可然物 (パルプ) が焼失して生ずる空隙のために多孔性である. この多孔性と成形加工性を活かして，触媒担体，吸着機能物など の分野で実用化研究の過程にある。成分配合と焼成結果を表 3 ・ $3 \cdot 1$ に，期待される用途を表 $3 \cdot 3 \cdot 2$ に示した.

ここでは製造方法について省略したが，䋐維のシート化と粘土 のような粉体物のシート化とは全く異質な技術であり，未だ完成 された技術ではなく多くの課題が存在する（表 $3 \cdot 3 \cdot 3 ）$.

\section{4. おわりに}

紙の長い歴史の中で，紙は「書く」，「拭う」，「包む」を基本的 機能として，基碟産業資材として発展してきた。本稿で概説した ように，機能紙は製紙産業の今日を支えるまでには至っていない， しかしながら，製紙産業との連係で他の産業が能動的に関与して いることも事契であり, 從来紙とは全く異なる分野での展開が期 待される，いわゆる「境界産業資材」として位置付けられるもの である。

本稿は「レオロジー」とは異なったものになり恐縮している. しかしながら，本稿の冒頭で触れたように，新規材料であるから こそ材料工学分野からの解明が要求される。

先にオーディオの世界を例に「感性」も機能だと言ったが，ス ピーカー・コーン紙の振動特性と「感性」は決して遊離している 課題ではない，昨今，オーディオ分野のハードウェアはデシタル 化され, 当然ながらデシタル信号に応答する振動板 (スピーカー ・コーン紙）の特性解析が要求される。そとのとは，「需要」を 前提とした「機能設計」の実体である。同様に，カーボン繊維を 利用したゴルフ用具や釣道具が生産されているが，それが娛楽用 具であるにしても，使用勝手の優劣の背景には何等かの材料特質 が存在するはずである．今後, 機能紙なる「紙」が材料工学の対 象となり，機能評価の方法が明らかにされるならば，機能設計ま たは機能強化の有力な手掛りとなろう。

無機㵶維の分散, 原料の流動, 填料の凝集, 抄紙適性, シート および加工物の物性評価など, 本学会と関連する課題は多い，今 後, 専門的な解析が加えられることを願って， あえて本稿を執筆 した次第である。
最後に, 紙上を借りて参考資料の提供者に深謝します。

\section{文献}

1）機能紙研究会（愛煖県川之江市川之江町港通912）。

2) High Performance Paper Society.

3）機能紙研究会, 昭和58年10月大会.

4）紙・パルプ技術タイムス，1月（1987）.

5）大野, 機能紙研究会誌, 20, Sept. (1981).

6）魚・畜肉の鮮度を測定する紙（昭和61年 8 月27日，日経産 業新聞).

7）杉原, 機能紙研究会誌, 21, Oct. (1983).

8）大野, 機能紙研究会誌, 20, Oct. (1981).

9）例光ば，日刊工業新聞（昭和61年 9 月26日）.

10）稲垣，紲パルプ技術タイムス「特集/無機㵶維紙」，4月 号 (1985).

11）松尾，紙パ技協誌，30，12，39（1976）.

12）五味，工業材料とその開発（化学工業社，1971）.

13）アイシン精器(㑣)カタログ.

14）内藤, 田中, 機能紙研究会誌, 22, Oct. (1983).

15）青木，松本，機能紙研究会誌，20，Oct. (1981).

16）小林良生，「バイオペーパー」(四国工業試験所調査).

17）岐阜県製紙試験場，土屋孝次氏提供.

18）著者，未発表.

19）著者, 未発表.

20）横山，中田，静岡県製紙工業試験場報告，第38号（昭和61 年).

21）稲垣，機能紙研究会誌，21, Oct. (1983).

22）門屋, 曰田, 大江, 製紙科学 (中外産業), p. 680 (1982).

23）三菱電機製品カタログ「ロスナイ」.

24）著者, 機能紙研究会誌, 17, Oct. (1978).

25）著者, 機能紙研究会誌, 18, Oct. (1979).

26）著者, 特公昭61-12729 (出願人: 静岡県外 1 名).

27）著者，繊維と工業，42，12，p. 491 (1986).

28）著者, 意匠登録, 昭54-045231 (出願人：静岡県外 1 名).

29）丸智工研(陎)（浜松市：静岡県之共同研究者).

30）著者, 実新案願昭61-108633 (出願人: 静岡県外 1 名).

31）特公昭 57-35147, 「通気性タイル施ユウ紙」，(出願人：巴 川製紙所)。

32）倉田, 久保島, 機能紙研究会誌, 23, Oct. (1984).

33）著者，紙パルプ技術タイムス，5月号 (1986).

34）著者, 特開昭60-155565, 「低温焼結性無機媜料及びその製 造法」, (出願人: 静岡県外 3 名). 